\title{
A (De)Formed Perception of The Pathway To Be Taken During The P. hD. The Influence Of Time In The Students' Eyes Perception In Becoming A Researcher
}

\author{
Isabel Ribau Coutinho \\ $\mathrm{PhD}$, Sustainable Chemistry, PhD, Educational Sciences \\ Centro Interdisciplinar de Ciências Sociais, \\ Universidade Nova de Lisboa, Portugal
}

\begin{abstract}
The PhD journey is different from all other activities in higher education. It's a period of construction of the research and is also a time for integration in the academy, in the field of research, and at the higher education system. During the enrolment in the PhD, the person's growth and the live experience change the perception that the doctorate has of the $\mathrm{PhD}$ and the research journey. The experiences as a doctoral student and as a researcher under construction, who is supervised/oriented/ guided by a supervisor, shape the way of thinking and action regarding the institution and the academy but also influence the way they see and felt the PhD journey and their beliefs. It is argued in this paper that an initial (de)formed perception of the real PhD journey and supervision, may influence the satisfaction of the students with it, and the disappointment impact the option to leave the academy or to continue. The current paper describes the change in the perception, motives, and of the curriculum quality and adequacy to doctoral personal journeys, during the doctorate. But it also reflects a PhD students' personal journey and their perceptions concerning the PhD supervisors, host institutions, and the academy.
\end{abstract}

\section{INTRODUCTION}

When a student enrols in a PhD, it has expectations, goals but also beliefs'. During the doctorate period, the living experience and the day-today-life change their perspectives, as they face reality, regarding the $\mathrm{PhD}$ experiences, the peers, the academy life, the research experience and environment, and the relation with the supervisor.

The PhD student - PhD supervisor relation/interaction is different from that of the master studentmaster supervisor or bachelor student - bachelor supervision, as doctoral programs and Master Programs have different goals and different pedagogies [Kleijn, Mainhard, Meijer, Pilot \& Brekelmans, 2012; Clarence, 2020]. And although a huge part, of the PhD students, knows already their supervisor, the relation change with time, as the PhD students usually face the transitions between a young adult to an adult, which transforms their perceptions and their judgments of their academic experience. And this is a challenge for supervisors. But this is not a unique change and challenge for doctoral education and particularly supervision, nowadays there are more mature 
Coutinho, I. R. (2020 A (De)Formed Perception Of The Pathway To Be Taken During The P. hD. The Influence Of Time In The Students' Eyes Perception In Becoming A Researcher. Advances in Social Sciences Research Journal, 7(11) 272-308.

students as $\mathrm{PhD}$ candidates and more diverse [Baptista, 2015Gube, Getenet, Satariyan \& Muhammad, 2017; Denis, Colet \& Lison, 2019]. The mature students left the academic environment, joined the job market outside the academy and, returned to the academy to take the $\mathrm{PhD}$ degree. During the time outside the academy, they grow as persons with new responsibilities as adults. Their conscience of the power difference between them and supervisor and, their (supervisors and students) duties and rights, but also the notion that the academy and host institutions, should be regulators of the supervision process, proposing good practices and the PhD quality and assessment, trigger the doctoral questioning regarding all their realities (why I'm doing this? what is the $\mathrm{PhD}$ utility? It is worthy?), and confront them with facts like attrition, the academy give-up, future careers, work market competence, failing, depression, but also with their wellbeing, happiness of discovery, knowledge construction, sense of belonging, and with the unknown not only in their personal but also in their professional life.

The $\mathrm{PhD}$ Journey is not only the research development and writing a thesis [Blaj-Ward, 2011; Clarence, 2020; DeClercq, Devos, Azzi, Frenay, Klein \& Galand, 2019; Humphrey, Marshall \& Leonardo, 2012]. It also implies personal and professional development, as a researcher identity is constructed. So doing a PhD must include practices, research strategies, and methodologies to fulfil the $\mathrm{PhD}$ goals, but also other parts: The researcher itself, the personal development, the interpersonal relationship with other researchers, but also to all persons (academic or not) that work in the same research environment, the Knowledge construction, the knowledge, the supervisor, the academy, the host institution, the academic culture, and the academic field culture, Fig. 1.
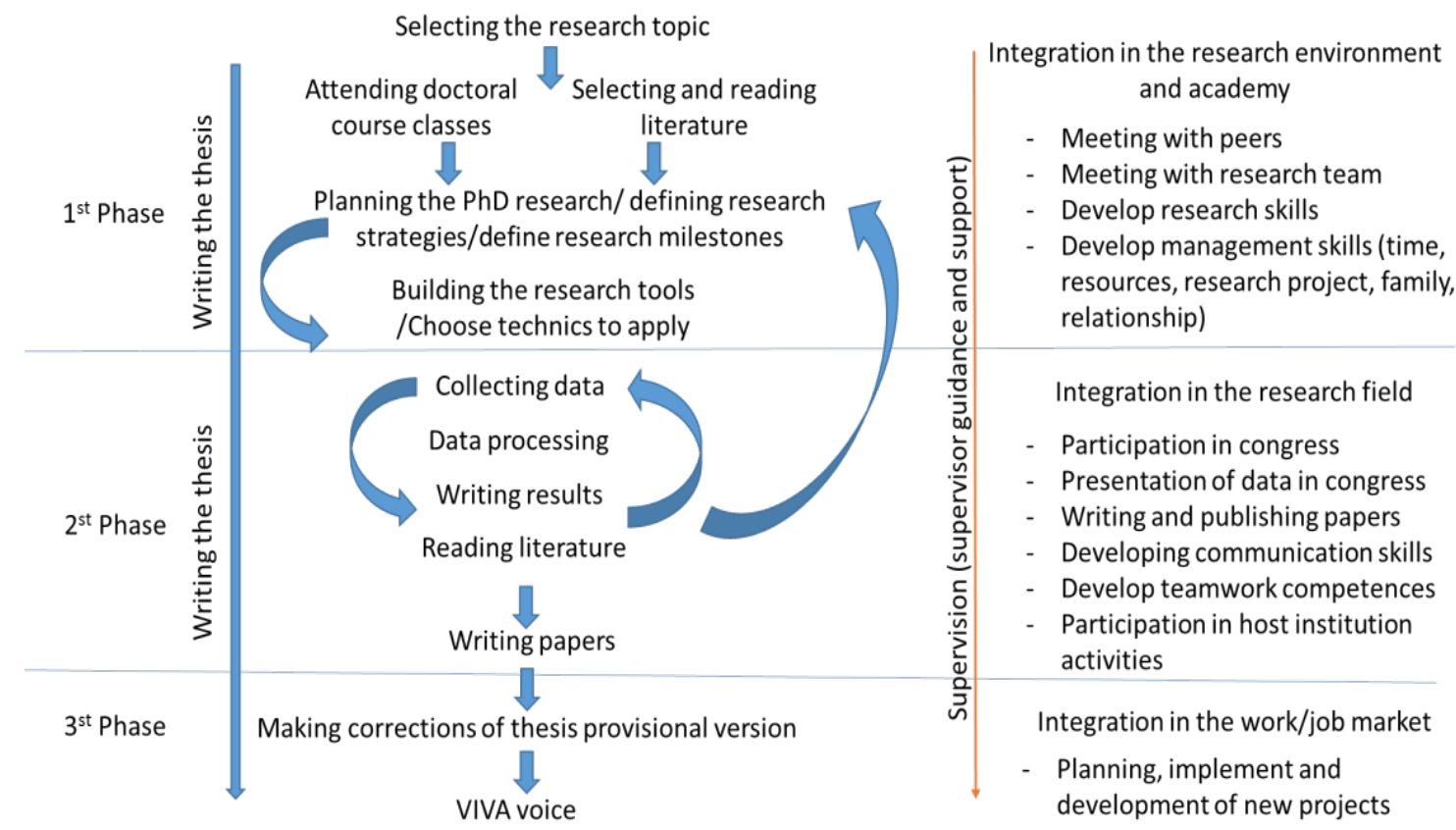

Figure 1. Tasks regarding the core of a doctoral journey. In the research process (column in the middle) the arrows represent the fluidity of the process during the doctoral journey. Supervision goes through all areas and during all phases.

During the PhD doctorate must acquire techniques, learn to build new ways of thinking and write, work in new environments - the academic research environment - and have to develop skills and 
abilities (competencies) in the area that are developing their work and create new knowledge (Ăkerlind \& McAlpine, 2017; Clarence, 2020). To achieve these goals, students have to feel safe, with their experiences and the feeling of belonging to the academy is a key part of their integration process in the academy (Gardner, 2008, 2008a, 2009 and 2010; DeClercq et al, 2019; van Rooij, Fokkens-Bruinsma \& Jansen, 2020). The similarity between the student's and the supervisor's perception and expectations ( the fit between them) of what a doctorate entails is important for the student to complete the doctorate (Holbrook, Shaw, Scevak, Bourke, Cantwell \& Budd, 2014; Orellana, 2016; Andrew, 2020; van Rooij, FokkensBruinsma \& Jansen, 2019; Masek, 2020).

But the integration of the student in the research environment is also important to promote the feeling of belonging, being an essential motivational aspect in the PhD process (Pyhältö, Vekkaila \& Keskinen, 2012; van Rooij, FokkensBruinsma \& Jansen, 2019). Some researcher realized that students' involvement in doctoral programs can be stimulated if students carry out activities that give them a sense of competence, belonging and autonomy, which increases their resilience to face challenges, being important for students to receive constructive and timely feedback, be encouraged to write and have a good relationship with the supervisor (Gardner, 2007 and 2008; Kamler, 2008; Pyhältö, Toom, Stubb \& Konka, 2009; Virtanan \& Pyhältö, 2012; Vekkaila, Pyhältö \& Lonka, 2013; van Rooij, Fokkens-Bruinsma \& Jansen, 2019). When doctorate achieve the milestones or goals that were defined in the $\mathrm{PhD}$ research plan they have a feeling of accomplishment fulfil that gives the motivation to continue the PhD journey.

The experiences of doctoral students can be analyzed taking into account the socialization process, the progress of the doctoral project, personal development, the motivation to pursue a doctorate, the support provided to the student, and discrimination and equity (Jones, 2013). The socialization process is very important for the PhD. If, on the one hand, contact between peers, promotes integration, reducing isolation, on the other hand, it also helps to understand the explicit and implicit rules as well as the cultures that govern the research environments in which they are integrating. In this way, students acquire knowledge, values, attitudes, and habits of the society where they want to be inserted (Golde, 1998 and 2007; Gardner, 2006, 2007, 2008).

Authors such as Gardner (2006, 2007, 2008 and 2009) and Golde (1998 and 2007) have emphasized the importance of this process since it may be the cause of many premature doctorate dropouts. Gardner proposes that the doctoral journey has three stages: entrance (which corresponds to the arrival at the higher education institution and to understand what is expected of a doctoral student and the first establishment of relations with colleagues and employees of the institution), integration (which is the moment to development of the doctoral project and the consolidation of the rules of the laboratory, research centre and strengthening of interpersonal relationships) and candidacy (corresponds to the systematization of results and writing of the thesis) (Gardner, 2009). Golde (1998) identifies four socialization tasks in PhD students (Intellectual mastery; realities of graduate life; professional preparation; departmental integration) that are associated with achievements: "intellectual competence; fitting in and surviving the struggle; clarification of career choice, career-life fit and balance".

In the area of natural science and engineering, workplace learning and the investigative environment in which it occurs will influence the experiences of doctoral students and dictate their success and should be taken into account when they start their doctorate (Hum, 2015). Results of 
Coutinho, I. R. (2020 A (De)Formed Perception Of The Pathway To Be Taken During The P. hD. The Influence Of Time In The Students' Eyes Perception In Becoming A Researcher. Advances in Social Sciences Research Journal, 7(11) 272-308.

Hum's research (2015) point out that "the inter-relationship between different elements related to individuals and context (s) in science doctoral work, and patterns in these inter-relationships. (...) Emphasize the importance of attending to the research work students engage in, and the affordances available to them, to ensure effective learning which can support student's learning and career goals." This author also draws attention to the fact that "What was needed for or defined, a successful/negative experience/outcome or affordance/hindrance" varied with the doctoral student and with the context. However, negative experiences in the workplace in the long term were characterized by multiple interrelated problems that prevented doctoral students from continuing their work and reaching their personal goals.

In recent years, studies related to self-efficacy (students' perception of their abilities to learn or implement school behaviours in a specific domain) have emerged (Overall et al., 2011; Rahmati, 2015), emotional exhaustion and well-being of PhD students (Pyhältö, Toom, Stubb \& Lonka, 2012; Rahmati, 2015; Hunter, Devine, 2016) and the relationship between goals, metacognition and academic success in higher education students (Coutinho, 2007; Kleijn, Mainhard, Meijer, Pilot \& Brekelmans, 2012; Hermita, Thamri, 2014). In these investigations it was found that depending on the supervisory experiences during the $\mathrm{PhD}$, this period can be felt like a time of personal and cognitive growth and integration in the communities of researchers and/or as a negative experience, a source of anxiety that generates exhaustion and burnout and that may lead to the abandonment of the academy (Yarwood-Ross \& Haigh, 2014; Rahmati, 2015; Hunter \& Devine, 2016). The results of these studies showed that the quality of the student-supervisor relationship is an important factor that can shape the experiences during the $\mathrm{PhD}$ course and can trigger stress and depression or motivation and satisfaction (Hunter \& Devine, 2016; Rahmati, 2015).

The key elements are the student, the supervisor, and the relationship he establishes between them. The supervisor is the student's link to the academy, the research process, the investigative environment, the university (administrative services), the physical space where the doctoral research takes place, having the role of intermediary between the student and the resources that he can use and the research it can perform. It is interesting to note that the research experiences lived during supervision reported by graduate students differ according to the background of the supervisors and are related to the quality of the supervision and also to the psychosocial attributes of the supervisors and their emotional intelligence (Abdullah \& Evans, 2012).

\section{CONTEXT}

Which are the pillars of a researcher? The high-quality knowledge and competence of the researcher (acquired competence in the first and second cycle), the Knowledge creation (autonomy, creativity, independence, precision and accuracy, ethic skills, resilience, procedural and attitudinal skills, abilities and competence), acceptance at the academy and in the research field (sense of belonging, culture, interconnection with peers), communication facilities (writing, reading, speaking) and personal development. But how to achieve all these goals? In the deformed perception, usually, the pathways of becoming a researcher have three steps: doing the research, writing the thesis and doing the viva Voice (or thesis defence - data presentation and argumentation), sometimes four (attendance to seminars or classrooms) or five (attendance to classes/ seminars, writing and publish a paper). But this is a simplification of all processes and the PhD pathways. 
The Dublin descriptors (http://ecahe.eu/w/index.php/Dublin_Descriptor, 2004) emphasize that the "Qualifications that signify completion of the third cycle are awarded to students" who develop not only systematic understanding of a field of study and mastery of the skills and methods of research associated with that field. But PhD students also must demonstrate the ability to conceive, design, implement and adapt a substantial process of research with scholarly integrity, which implies a contribution through original research.

They must be capable of critical analysis, evaluation, and synthesis of new and complex ideas and can communicate with their peers, the larger scholarly community, and with society in general about their areas of expertise, and also be able to promote, technological, social or cultural advancement in a knowledge-based society. To achieve all of these goals are necessary not only to promote a friendly research environment, to give financial funding but also to give personal assistance and support as the journey is not always linear and successful. The "Joint Statement of the Research Councils Skills Training Requirements for Research Students" refers that outlines training should focus, research skills and techniques, research environment, research management, personal effectiveness, communication skills, networking, and teamwork but also career management (retrieved from https://www.dmu.ac.uk/documents/doctoralcollege/currentstudents/research-development-programme/jointstatement.pdf at 10jun2020). So the journey is much more demanding and comprehensive, compelling to have supervision not only restricted to research (research techniques and methodologies) to the writing and defence of the thesis but to develop holistic supervision that involves all the areas mentioned above.

\section{Context}

\section{METHODOLOGY}

Since 1997 the number of students enrolled in the PhD has grown in Portugal until 2011, then it began to stabilize, Fig 2 . This implied an increasing number of doctoral students that didn't have a place in the academy. The number of students enrolled at Universidade Nova de Lisboa, between the academic year 2010/2011 and 2017/2018 is presented in Fig.2 (data retrieved from http://dgeec.mec.pt/np4/raides/RAIDES accessed in May 2020). It is important to highpoint the academic year of the implementation of the Bologna Process for the third cycle in Portugal (2006/2007), this was not fundamental for the third cycle growth but may be the trigger to include mature students in the system as partial-time enrolment was allowed. Another important data was $2008 / 2009$ when the collection of the data concerning Higher Education (RAIDES) started. This last action provided data that allowed the characterization of the doctoral population more precisely. 




Figure. 2 Number of PhD students enrolled for the first time in the PhD, in Portugal, since the scholar years of 1995/1996. Insertion: Number of students enrolled for the first time in PhD before and after the implementation of the Bologna process in the third cycle in Portugal. Data retrieved from https://www.dgeec.mec.pt/np4/1057.html. In the legend of the graphic: 2006/07 b) Beginning of the Bologna Process (Decree-Law no. 74/2006, of 24 March).

2008/09 c) Beginning of the collection of the Register of Registered Students and Graduates of Higher Education (RAIDES). Main graph (-) PhD courses at UNL and $(-)$ in all Portuguese Universities. (-) PhD courses, organized before Decree-Law no. 74/2006, of 24 March (in extinction) and (-) PhD courses organized following Decree-Law No. 74/2006, of 24 March (Bologna Process). The Register of Enrolled and Graduated Students of Higher Education (RAIDES) is an annual survey, nationwide, addressed to all higher education institutions. RAIDES is a mandatory answer instrument of the National Statistical System (Law No. 22/2008, of 13 May), registered with INE under No. 10259. 
From the RAIDES data, it is also possible to know the average number of PhD students, enrolled for the first time, between 2010 and 2018, in the school of science and technology at the NOVA Lisbon University, Table 1.

Table 1. The number of students enrolled in the 1 st year of the PhD course at the Universidade Nova de Lisboa.

\begin{tabular}{|c|c|}
\hline Year & $\begin{array}{c}\text { Number of } \\
\text { students enrolled }\end{array}$ \\
\hline $2010 / 2011$ & 589 \\
\hline $2011 / 2012$ & 539 \\
\hline $2012 / 2013$ & 563 \\
\hline $2013 / 2014$ & 494 \\
\hline $2014 / 2015$ & 456 \\
\hline $2015 / 2016$ & 546 \\
\hline $2016 / 2017$ & 527 \\
\hline $2017 / 2018$ & 521 \\
\hline $2018 / 2019$ & 532 \\
\hline Average & $\mathbf{5 3 0}$ \\
\hline
\end{tabular}

\section{Methodology}

NOVA School of Science and Technology belongs to Universidade Nova de Lisboa, which is a Portuguese public higher education institution, with high levels of research inputs, being the school of engineering and natural science at this university [Ribau, 2018, 2019 and 2020; Ribau \& Alves, 2017 and 2018]. This school has a strong research environment; it has eight European Research Council (ERC) grants, which support top researchers to continue their top research ( Project INVISIBLE - Advanced Amorphous Multicomponent Oxides for Transparent Electronics; Project SCENT - Hybrid Gels for Rapid Microbial Detection; Project - NEW_FUN - New era of printed paper electronics based on advanced functional cellulose; Project - CapTherPV - Integration of Capacitor, Thermoelectric and PhotoVoltaic thin films for efficient energy conversion and storage; Project TREND - Transparent and flexible electronics with embedded energy harvesting based on oxide nanowire devices; Project- Des.solve - When solids become liquids: natural deep eutectic solvents for chemical process engineering Project - Multifunctional Digital Materials Platform for Smart Integrated Applications | DIGISMART; Project - Cellulose Aluminium Polymer multi-ions composite Solidelectrolyte (CAPSEL). Data retrieved from https://www.unl.pt/investigacao/bolsas-erc in 4 September 2020.).

To characterize from the doctorate point of view, namely the reasons to enrol and proceeding the doctorate, the quality, and the skills development, but also the importance of some characteristics in the supervisor, a survey was constructed and applied.

\section{Procedure}

A questionnaire, to capture the perceptions of the $\mathrm{PhD}$ students regarding the supervision practices, quality of the $\mathrm{PhD}$, and the supervisor was prepared and delivered in the year 2019, between May and July 2019, via institutional e-mail at NOVA School of Science and Technology, to the PhD 
Coutinho, I. R. (2020 A (De)Formed Perception Of The Pathway To Be Taken During The P. hD. The Influence Of Time In The Students' Eyes Perception In Becoming A Researcher. Advances in Social Sciences Research Journal, 7(11) 272-308.

students. This paper reports the end-questions of this survey, regarding the reasons to apply for a $\mathrm{PhD}$, the quality concerning the adequacy of the curriculum $\mathrm{PhD}$, namely the competencies developed, the methodologies used, physical conditions, the Importance of the supervisor, and the difficulties during the doctoral journey.

The survey was open for three months. Eighty-eight doctoral students responded, which corresponds to $16.5 \%$ of all PhD students enrolled at NOVA School of Science and Technology, UNL. The main goal of this research was to characterize doctoral education in this school and particularly the quality of the Curriculum from the students' eyes and have clues to improve it. Some hypothesis was proposed: $\mathrm{H} 1$ : The perceptions regarding the $\mathrm{PhD}$ reasons to apply and to be enrolled on it are different; $\mathrm{H} 2$ : The awareness regarding the $\mathrm{PhD}$ curriculum quality change over time; H3: The opinions regarding the competencies developed during the $\mathrm{PhD}$ change with enrolment time.

\section{Participants -Sample characterization}

In 2019 (year of the survey implementation) the number of PhD students enrolled at NOVA School of Science and Technology (FCT UNL) was 532, 258 men, and 274 women (RAIDES 2019). Only 88 of these PhD students responded to the questioner. Two doctoral students had bachelor after Bologna implementation, one had Bachelor before bologna, sixty had a master degree, and twentyfive Integrated Master degree (the student have a journey of 5 years when they went to the school3 years to have a bachelor linked to two more years, and only then they have the master degree. Usually, this happens in an engineering degree (https://www.fct.unl.pt/en/education/masterdegrees)9.

The students' age range between 23 years old and more than 51 years old, but $66 \%$ of the students' sample had between 26 and 35 years old (Table 2), 16\% of the total respondents are enrolled at partial-time and $84 \%$ at full-time.

Table 2. The age range of $\mathrm{PhD}$ doctorate respondents.

\begin{tabular}{|c|c|c|}
\hline Age range & $\begin{array}{c}\text { number of } \\
\text { students }\end{array}$ & $\begin{array}{c}\text { percentage } \\
\mathbf{\%}\end{array}$ \\
\hline $23-25$ & 10 & $11 \%$ \\
\hline $26-30$ & 37 & $42 \%$ \\
\hline $31-35$ & 21 & $24 \%$ \\
\hline $36-40$ & 8 & $9 \%$ \\
\hline $41-45$ & 5 & $6 \%$ \\
\hline $46-51$ & 5 & $6 \%$ \\
\hline $51>$ & 1 & $1 \%$ \\
\hline $\begin{array}{c}\text { Did not } \\
\text { answer }\end{array}$ & 1 & $1 \%$ \\
\hline & $\mathbf{8 8}$ & $\mathbf{1 0 0 \%}$ \\
\hline
\end{tabular}

Forty-nine per cent of the respondents are women, with an average age of 30 years old, but with an age range from 23 years old to 59 years old. Fifty-one per cent of the survey respondents were men, with an average age of 34 years old and an age range between 24 and 51 years old. 
Regarding the first year of enrolment, it is possible to perceive that the enrolment year of the respond students was from 2011 to 2019 , but $50 \%$ of them started their first enrolment in the years 2017 and 2018, Table 3.

Table 3. Year of enrolment in the PhD

\begin{tabular}{|c|c|c|c|c|}
\hline $\begin{array}{l}\text { Year of the first } \\
\text { enrollment in the } \\
\text { PhD }\end{array}$ & $\begin{array}{c}\begin{array}{c}\text { number } \\
\text { of } \\
\text { students }\end{array} \\
\end{array}$ & $\begin{array}{l}\text { Percentage } \\
\text { of students }\end{array}$ & $\begin{array}{l}\% \text { men and } \\
\text { average age }\end{array}$ & $\begin{array}{c}\text { \% women } \\
\text { and average } \\
\text { age }\end{array}$ \\
\hline 2011 & 1 & $1 \%$ & \multirow{5}{*}{$54 \% ; 34.5$} & \multirow{5}{*}{$46 \% ; 32.5$} \\
\hline 2012 & 2 & $2 \%$ & & \\
\hline 2013 & 1 & $1 \%$ & & \\
\hline 2014 & 10 & $11 \%$ & & \\
\hline 2015 & 12 & $14 \%$ & & \\
\hline 2016 & 13 & $15 \%$ & \multirow{2}{*}{$54 \% ; 33$} & \multirow{2}{*}{$46 \% ; 31$} \\
\hline 2017 & 24 & $27 \%$ & & \\
\hline 2018 & 20 & $23 \%$ & \multirow{2}{*}{$42 \% ; 36$} & \multirow{2}{*}{$54 \% ; 27$} \\
\hline 2019 & 4 & $5 \%$ & & \\
\hline Didn't respond & 1 & $1 \%$ & & \\
\hline Total & 88 & $100 \%$ & $51 \% ; 34$ & $49 \% ; 30$ \\
\hline
\end{tabular}

Deepening the analysing of data survey concerning the first year of enrolment, there are $46 \%$ of women, with an average age of 32,5 years old, and 54\% of men with an average age of 34,5 years old, inscribed for the first time in the PhD between 2011 and 2015, Table 3. Looking to the sample that enrolled for the first time between 2016 and 2017, it is possible to perceive that $46 \%$ are women (average age of 31 years old) and $54 \%$ are men (average age of 33 years old). If we look to the data referred to the first enrolment time between 2018 and 2019, there are 54\% of women with an average age of 27 years old, and $42 \%$ of men's with the middle age of 36 years old (there are respondents that didn't put the age in the survey). It is possible to conclude that men are older than women in the same year of enrolment and that women usually start their PhD sooner than men.

There are $37 \mathrm{PhD}$ courses at FCT UNL (Table 4) but from nine of them, no students answered. From these data, It is possible to perceive that are more women (274) enrolled in the PhD courses than men (258) and that the PhD courses with more students enrolled for the first time were Electrical and Computer Engineering (57 students enrolled for the first time - 44 men and 13 women) and the PhD course with lower students enrolled were Atomic and Molecular Physics (1 student enrolled for the first time - a woman), Table 4. There are PhD courses which have a differential between Women and men higher than 70\% such as "Environment and Sustainability", "Bioengineering", "Biology", "Chemical and Biochemical Engineering "Civil Engineering", "Electrical and Computer Engineering", "Computer Science", "Conservation and restoration of cultural heritage". Fourteen PhD courses need at least 3 years to complete, twenty PhD courses need 4 years to complete and one can take between 4 to 5 years to conclude (Data regarding the PhD courses retrieved on 1 Jun of 2020 from https://www.fct.unl.pt/en/education/phd-programmes, Table 4.) 
Coutinho, I. R. (2020 A (De)Formed Perception Of The Pathway To Be Taken During The P. hD. The Influence Of Time In The Students' Eyes Perception In Becoming A Researcher. Advances in Social Sciences Research Journal, 7(11) 272-308.

Table 4 PhD Course and the number of students' enrolled for the first time in PhD courses in FCT (Data retrieved from RAIDES 19) and the number of students' respondents. Data regarding the PhD courses retrieved from https://www.fct.unl.pt/en/education/phd-programmes at 1 jun2020.

\begin{tabular}{|c|c|c|c|c|c|c|c|c|}
\hline \multirow{2}{*}{$\begin{array}{l}\text { PhD Course name (institutional } \\
\text { time, in years, to complete) }\end{array}$} & \multicolumn{3}{|c|}{$\begin{array}{c}\text { Number of students } \\
\text { enrolled 2018/2019) } \\
\text { (DADOS RAIDES 19) }\end{array}$} & \multirow{2}{*}{$\begin{array}{c}\text { Percentage } \\
*\end{array}$} & \multicolumn{3}{|c|}{$\begin{array}{l}\text { Survey responses Jun } \\
2019\end{array}$} & \multirow{2}{*}{\begin{tabular}{|c|}
$\%$ \\
Percentage \\
of \\
responses \\
per course
\end{tabular}} \\
\hline & $\mathbf{M}$ & $\mathbf{W}$ & MW & & $\mathbf{M}$ & $\mathbf{W}$ & MW & \\
\hline $\begin{array}{l}\text { Climate Change and Sustainable } \\
\text { Development Policies }\left(3^{*}\right)\end{array}$ & 5 & 4 & 9 & $2 \%$ & 0 & 1 & 1 & $1 \%$ \\
\hline Environment and Sustainability (3) & 7 & 17 & 24 & $5 \%$ & 2 & 1 & 3 & $3 \%$ \\
\hline Technology Assessment** & 3 & 2 & 5 & $1 \%$ & 1 & 0 & 1 & $1 \%$ \\
\hline Molecular Biosciences $\left(4^{*}\right)$ & 3 & 6 & 9 & $2 \%$ & 0 & 0 & $\mathbf{0}$ & $0 \%$ \\
\hline Bioenergy (3) & 8 & 8 & 16 & $3 \%$ & 0 & 3 & 3 & $3 \%$ \\
\hline $\begin{array}{c}\text { Bioengineering (MIT) (between } 4 \text { and } \\
5 \text { years) }\end{array}$ & 4 & 13 & 17 & $3 \%$ & 0 & 2 & 2 & $2 \%$ \\
\hline $\begin{array}{l}\text { Radiation Biology and Biophysics } \\
\text { (RABBIT) (4) }\end{array}$ & 14 & 14 & 28 & $5 \%$ & 6 & 1 & 7 & $8 \%$ \\
\hline Biology (4) & 3 & 20 & 23 & $4 \%$ & 0 & 4 & 4 & $5 \%$ \\
\hline Biochemistry (4) & 2 & 3 & 5 & $1 \%$ & 0 & 0 & $\mathbf{0}$ & $0 \%$ \\
\hline Biotechnology (4) & 1 & 2 & 3 & $1 \%$ & 1 & 0 & 1 & $1 \%$ \\
\hline Science and Materials Engineering (4) & 3 & 8 & 11 & $2 \%$ & 0 & 1 & 1 & $1 \%$ \\
\hline Education (3) & 5 & 10 & 15 & $3 \%$ & 3 & 0 & 3 & $3 \%$ \\
\hline Food Sciences (4) & 4 & 9 & 13 & $2 \%$ & 2 & 0 & 2 & $2 \%$ \\
\hline $\begin{array}{c}\text { Conservation and Restoration of } \\
\text { Cultural Heritage (4) }\end{array}$ & 3 & 24 & 27 & $5 \%$ & 0 & 6 & 6 & $7 \%$ \\
\hline Biomedical Engineering (4) & 17 & 10 & 27 & $5 \%$ & 3 & 1 & 4 & $5 \%$ \\
\hline Civil Engineering (3) & 18 & 5 & 23 & $4 \%$ & 2 & 0 & 2 & $2 \%$ \\
\hline \begin{tabular}{|c|} 
Refining, Petrochemical and Chemical \\
Engineering (3)
\end{tabular} & 1 & 2 & 3 & $1 \%$ & 0 & 0 & $\mathbf{0}$ & $0 \%$ \\
\hline Membrane Engineering (EUDIME) $(* *)$ & 2 & 1 & 3 & $1 \%$ & 0 & 1 & 1 & $1 \%$ \\
\hline $\begin{array}{c}\text { Electrical and Computer Engineering } \\
(4)\end{array}$ & 44 & 13 & 57 & $11 \%$ & 1 & 2 & 3 & $3 \%$ \\
\hline Physics Engineering (4) & 4 & 1 & 5 & $1 \%$ & 1 & 0 & 1 & $1 \%$ \\
\hline Geological Engineering (3) & 2 & 1 & 3 & $1 \%$ & 0 & 0 & $\mathbf{0}$ & $0 \%$ \\
\hline Industrial Engineering (3) & 12 & 8 & 20 & $4 \%$ & 2 & 0 & 2 & $2 \%$ \\
\hline Mechanical Engineering (3) & 4 & 1 & 5 & $1 \%$ & 2 & 0 & 2 & $2 \%$ \\
\hline $\begin{array}{c}\text { Chemical and Biochemical Engineering } \\
(4)\end{array}$ & 3 & 20 & 23 & $4 \%$ & 2 & 7 & 9 & $10 \%$ \\
\hline E-Planning (3) & 1 & 3 & 4 & $1 \%$ & 0 & 0 & $\mathbf{0}$ & $0 \%$ \\
\hline Statistics and Risk Management $(* *)$ & 7 & 7 & 14 & $3 \%$ & 0 & 1 & 1 & $1 \%$ \\
\hline Atomic and Molecular Physics (4) & 0 & 1 & 1 & $0 \%$ & 0 & 0 & $\mathbf{0}$ & $0 \%$ \\
\hline
\end{tabular}




\begin{tabular}{|c|c|c|c|c|c|c|c|c|}
\hline Geology (3) & 3 & 0 & $\mathbf{3}$ & $\mathbf{1 \%}$ & 0 & 0 & $\mathbf{0}$ & $\mathbf{0 \%}$ \\
\hline $\begin{array}{c}\text { History, Philosophy and Heritage of } \\
\text { Science and Technology (3) }\end{array}$ & 5 & 4 & $\mathbf{9}$ & $\mathbf{2 \%}$ & 3 & 0 & $\mathbf{3}$ & $\mathbf{3 \%}$ \\
\hline Computer Science (4) & 25 & 3 & $\mathbf{2 8}$ & $\mathbf{5 \%}$ & 4 & 1 & $\mathbf{5}$ & $\mathbf{6 \%}$ \\
\hline Mathematics (3) & 7 & 2 & $\mathbf{9}$ & $\mathbf{2 \%}$ & 1 & 0 & $\mathbf{1}$ & $\mathbf{1 \%}$ \\
\hline $\begin{array}{c}\text { Advanced Materials and Processing } \\
(4)\end{array}$ & 2 & 2 & $\mathbf{4}$ & $\mathbf{1 \%}$ & 0 & 1 & $\mathbf{1}$ & $\mathbf{1 \%}$ \\
\hline $\begin{array}{c}\text { Digital Media (4) } \\
\text { (4) }\end{array}$ & 6 & 8 & $\mathbf{1 4}$ & $\mathbf{3 \%}$ & 2 & 1 & $\mathbf{3}$ & $\mathbf{3 \%}$ \\
\hline $\begin{array}{c}\text { Nanotechnologies and Nanosciences } \\
\text { Chemistry (4) }\end{array}$ & 6 & 8 & $\mathbf{1 4}$ & $\mathbf{3 \%}$ & 0 & 0 & $\mathbf{0}$ & $\mathbf{0 \%}$ \\
\hline Sustainable Chemistry (4) & 12 & 16 & $\mathbf{2 8}$ & $\mathbf{5 \%}$ & 3 & 5 & $\mathbf{8}$ & $\mathbf{9 \%}$ \\
\hline Agroindustrial Technologies (3) & 6 & 10 & $\mathbf{1 6}$ & $\mathbf{3 \%}$ & 0 & 0 & $\mathbf{0}$ & $\mathbf{0 \%}$ \\
\hline Did not respond & & & & & 1 & 1 & $\mathbf{2}$ & $\mathbf{2 \%}$ \\
\hline ToTal & 258 & 274 & 532 & $\mathbf{1 0 0 \%}$ & 45 & 43 & $\mathbf{8 8}$ & $\mathbf{1 0 0} \%$ \\
\hline
\end{tabular}

*representativeness of the enrolments in the first years in each doctoral course, regarding the FCT total doctoral courses. M-men; W-women, MW-men, and women. $3^{*}-3$ years correspond to $180 \mathrm{ECTS}$; ${ }^{* *}$ without information; $4^{*}-4$ years correspond to 240 ECTS (information retrieved from https://www.fct.unl.pt/ensino/doutoramentos on 30 July 2020).

\section{Data}

The data presentation is organized considering the motives that lead doctoral students to make their application to a $\mathrm{PhD}$ followed by the reasons that they have to continue in the PhD. The following item is the tasks that doctoral students were doing in the PhD. The quality of the PhD from the student's point of view was assessed, as the development of competencies /Skills related to the PhD process and the difficulties inherent to it. Finally, a look at the degree of the importance of some supervisor characteristics was assessed by doctoral students. All these data were analysed having in mind the change that occurred during the doctorate, which implied sometimes grouping data from different years of the first enrolment.

Results

\section{Reasons to apply for a PhD}

It's important to know the reasons that were underlying the PhD application since this is at the beginning of the PhD journey. The doctoral students had to select from a range of reasons, indicated in the survey, which were the ones that fit with their situation, Table 5 . These sentences were based on previous research work (Ribau, 2018, 2019 and 2020). 
Table 5. Reasons to apply for a PhD

\begin{tabular}{|c|c|}
\hline Reasons to apply to a PhD... & $\begin{array}{l}\text { Percentage } \\
\text { of responses }\end{array}$ \\
\hline For professional career progression. & $51 \%$ \\
\hline I like challenges. & $49 \%$ \\
\hline I like to learn. & $49 \%$ \\
\hline For personal enrichment/enhancement. & $48 \%$ \\
\hline It is good for my life project. & $47 \%$ \\
\hline I like (liked) the project. & $41 \%$ \\
\hline $\begin{array}{c}\text { For personal and/or professional interest in } \\
\text { deepening a topic. }\end{array}$ & $33 \%$ \\
\hline It is necessary for my professional career. & $30 \%$ \\
\hline I like (liked) working with the supervisor. & $27 \%$ \\
\hline $\begin{array}{l}\text { It will be a gateway to my future career as a } \\
\text { researcher in higher education. }\end{array}$ & $26 \%$ \\
\hline $\begin{array}{l}\text { It will be a gateway to my future career as a } \\
\text { teacher in higher education. }\end{array}$ & $26 \%$ \\
\hline $\begin{array}{l}\text { I can (I will) do research work at a foreign } \\
\text { university. }\end{array}$ & $23 \%$ \\
\hline $\begin{array}{l}\text { For career advancement, outside the Higher } \\
\text { Education system. }\end{array}$ & $18 \%$ \\
\hline Curiosity. & $16 \%$ \\
\hline Vocation. & $15 \%$ \\
\hline To have a scholarship. & $8 \%$ \\
\hline Lack of jobs. & $6 \%$ \\
\hline $\begin{array}{l}\text { Colleagues had already told me well about the } \\
\text { PhD. }\end{array}$ & $3 \%$ \\
\hline Influence of my supervisor. & $1 \%$ \\
\hline
\end{tabular}

Half of the sample identifies the professional career progression as the main motive to start the PhD, $49 \%$ also refer to challenges, and enjoy learning. Almost half of the doctorate indicates that the enrolment in a PhD was for personal enrichment and was good for their life project. The application to the PhD is related to internal motivation and reflect personal aims. But the motives to continue attending the $\mathrm{PhD}$ are related not only related to internal but to external motivation.

\section{Reasons to continue attending and be engaged in the PhD}

Considering that some students had been doing their PhD for eight years, it was important to know why they continued to be enrolled in the $\mathrm{PhD}$, and what their difficulties were. It is also important for the institution and supervisors, to know the reasons that lead a doctoral student to continue and persisted in the PhD, since it is usually hard and exhausting. Here also, the respondents had to select from a range of reasons, indicated in the survey, which were the ones that were more suitable to them. 
More than half of the doctorate identifies personal reasons as the main reason to pursue a PhD (Learning and knowledge acquisition) but assign also professional reasons (Progress in a professional career). Forty-four per cent consider that they are engaged in PhD because they like what they are doing in the $\mathrm{PhD}$, and because is an opportunity to promote personal development. Only 35\% selected the option "Belong to the academic/scientific Community" and 34\% "It makes me feel intellectually fulfilled". Twenty-eight per cent identified the issue "To improve professional performance", and "To meet my expectations", Table 6.

Table 6. Reasons to continue the PhD journey

\begin{tabular}{|c|c|}
\hline $\begin{array}{c}\text { The most important reasons to continue } \\
\text { enrolled in the PhD }\end{array}$ & $\begin{array}{l}\text { Percentage } \\
\text { of responses }\end{array}$ \\
\hline Learning and acquiring knowledge. & $57 \%$ \\
\hline Progress in a professional career. & $55 \%$ \\
\hline I like what I do at the PhD. & $44 \%$ \\
\hline The opportunity to promote personal development. & $44 \%$ \\
\hline Belong to the academic/scientific community. & $35 \%$ \\
\hline It makes me feel intellectually fulfilled. & $34 \%$ \\
\hline To improve professional performance. & $28 \%$ \\
\hline To meet my expectations. & $28 \%$ \\
\hline I like the research topics. & $27 \%$ \\
\hline Because I like it. & $26 \%$ \\
\hline $\begin{array}{l}\text { I feel happy and in a good mood when I am } \\
\text { working on the development of my PhD project. }\end{array}$ & $25 \%$ \\
\hline $\begin{array}{l}\text { The opportunity to promote professional } \\
\text { development. }\end{array}$ & $25 \%$ \\
\hline The PhD project corresponds to my expectations. & $24 \%$ \\
\hline To find a better-paid job. & $23 \%$ \\
\hline Better chances of finding a job. & $19 \%$ \\
\hline Because I would like to have a doctor's degree. & $17 \%$ \\
\hline Have a scholarship. & $16 \%$ \\
\hline Professional dissatisfaction. & $6 \%$ \\
\hline The location of the school. & $5 \%$ \\
\hline Being unemployed.; & $3 \%$ \\
\hline To maintain the working position.; & $3 \%$ \\
\hline To change the job. & $2 \%$ \\
\hline
\end{tabular}

The reasons to apply for a $\mathrm{PhD}$ and to continue are not the same. The reasons change from predominantly personal initially, to a more professional and at last to economic and financial. This transformation is related to personal growth, but also the real $\mathrm{PhD}$ life and experience. 
It is possible to verify, from table 6 , that the reasons invoked by doctoral students to apply to a PhD are professional (professional career), but, above all, they are personal reasons (appreciate the challenges, like to learn, personal enrichment). But over time, the PhD experiences and the rise of new perception related to the reality of the $\mathrm{PhD}$ life leads to changes in the aims of being enrolled in $\mathrm{PhD}$, Table 7. The initial objectives change. They pass from personal (subjective) to professional (objective). This rationalization can be a strategy to overcome the difficulties felt by the doctorate and also overcome the personal disenchantment/ disappointment/ dissatisfaction with the PhD journey. The rationalization together with the assignment of new goals also favours personal wellbeing and allows the doctorate to continue involved and engaged in the doctorate. This change in the doctorate goals can be related to many factors, the $\mathrm{PhD}$ curriculum/design, supervisors relation, supervisor guidance, socialization/sense of belonging to the academy, lake of equipment/resources or conditions to do the research project, personal conditions and support (family, employment, financial support, personal problems) and so on.

Considering the reasons (personal, professional, and economic-financial) as dimensions, and taking into account that they can have different orientations (they can be extrinsic and intrinsic), a model was defined for the orientation and reasons to perform and accomplish a PhD, Fig. 3.

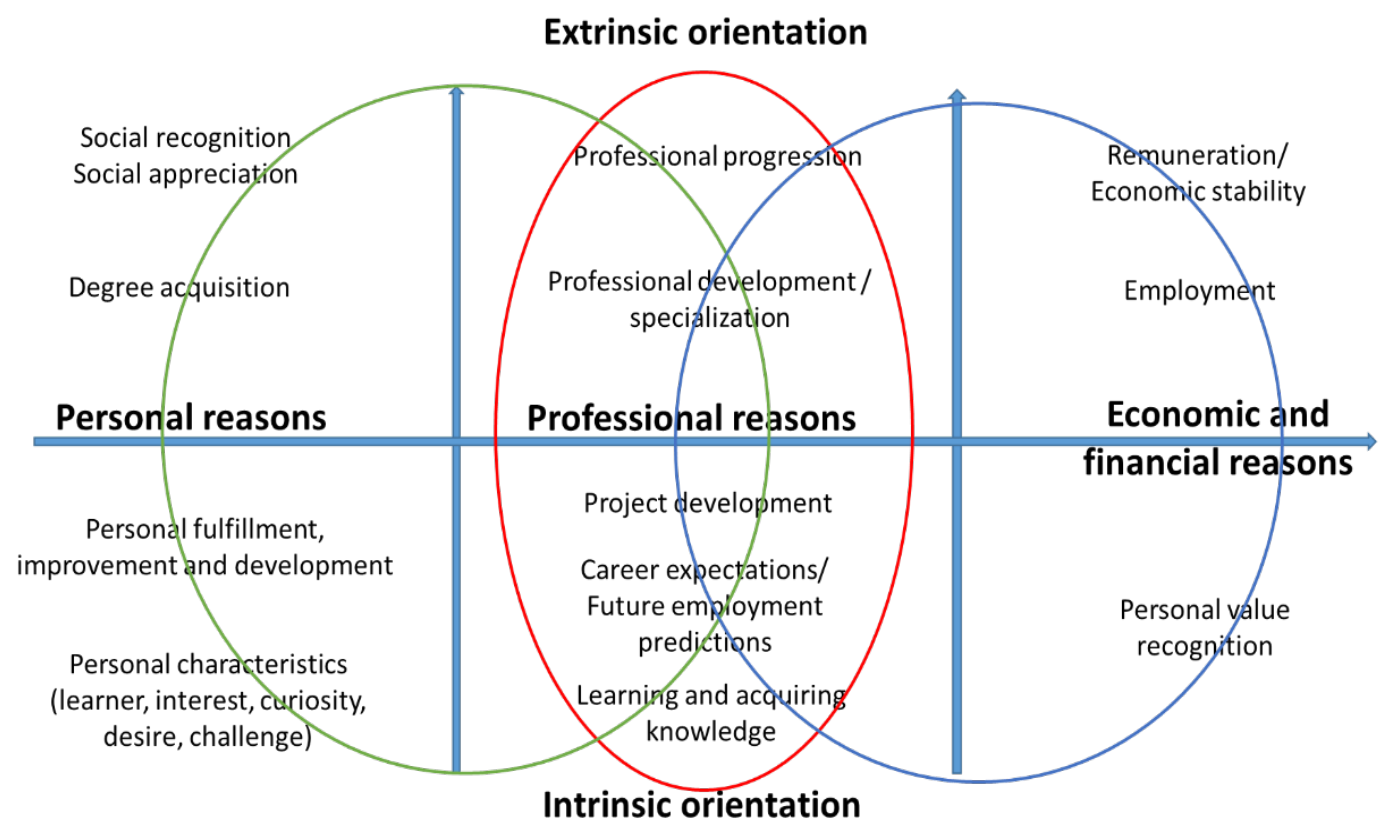

Figure 3. Guidelines (extrinsic or intrinsic) and reasons for involvement in the doctorate. Green area- reasons to apply to a $\mathrm{PhD}$; red area- reasons to engage in the $\mathrm{PhD}$; Blue-- reasons to finish/complete the PhD

The two dimensions of this model, motives/reasons and orientation, define two axes and are related to causes of being enrolled in PhDs, which can be more extrinsic or more intrinsic (orientation) depending on this classification of the social visibility they have, of being more or less personal. Personal reasons can be intrinsic and extrinsic and are related to personal improvement and appreciation, with the acquisition of the degree and personal fulfilment, and personal characteristics, such as appreciate challenges, have the curiosity, the interest for research and science, and the opportunity to improve. Professional reasons are also extrinsic and intrinsic and 
relate to the valorisation and recognition by society, with specialization, progression, and professional development / continuing the academic path, with the entry into the academic or research career, but also with learning or acquire more knowledge and develop a project. But emerge also economic and financial reasons, which can be related to intrinsic or extrinsic orientation as the person recognise their value (intrinsic orientation) and desires for better salary/remuneration and economic stability (extrinsic orientation).

This model reflects the change in perceptions of the PhD journey. When a doctorate does the application the main reasons are personal thought the professional reason exists (professional progression). The professional reasons emerge as the hardness of the journey is revealed. After the first impact of the life experience in the doctorate, the perception of reality leads to rationalization, which is required to continue attending the $\mathrm{PhD}$. This process leads to alteration in reasons to attend the $\mathrm{PhD}$, they become essentially professional (red area). In the last phase of the PhD, the reasons move to more objective and instrumental reasons- the economic and financial ones. And these three motives guide the doctorate during the PhD and may be related to personal growth and with the meaning of having a PhD. To continue to be motivated and engage in the PhD, doctorate search new personal meanings, as he or she faces the society and family, the necessity of monetary independence and economic stability, and the options of continuing or give up of the doctoral journey and enter in the work Market. In this context were important to find the difficulties found by doctorate, to mitigate them.

\section{Difficulties in the PhD}

In the survey, the PhD students were also asked to reflect on what they considered the most difficult thing in the PhD. The sentences presented were related to research competence development, personal factors, to the relationship with the supervisor, and with the integration and relatedness in the academy. In the research competence development, time management presents great difficulties for $49 \%$ of the doctorate that responded to the survey, but also publishes Papers (great difficulties to $49 \%$ of the sample), being these more relevant in men, Table 8 . At this point, it should be mentioned that, although it is not possible with this results to relate the difficulties regarding writing papers with the lack of supervisors involvement and commitment with the PhD project, particularly with the writing process. In this academic institution, there are no writing centres or any tradition regarding academic students support units, to help students in this task. So if a supervisor doesn't teach and help to develop writing skills and mastering scientific writing, students are alone in the task.

Regarding personal factors, it is alarming that almost half of the sample (48\%) feels demotivation regarding the $\mathrm{PhD}$, being this more relevant for women $(51 \%$ of the women that responded to the questionnaire). Another difficulty is the management of the doctorate and family life (sense by $47 \%$ of the women, but also $44 \%$ of men), and the financial support (felt for $40 \%$ of women and men). A third of the sample also considers it difficult to be satisfied with the research work and with their efficiency in resolving research problems, Table 8. 
Coutinho, I. R. (2020 A (De)Formed Perception Of The Pathway To Be Taken During The P. hD. The Influence Of Time In The Students' Eyes Perception In Becoming A Researcher. Advances in Social Sciences Research Journal, 7(11) 272-308.

\section{Table 8. The most difficult thing in the PhD journey is...}

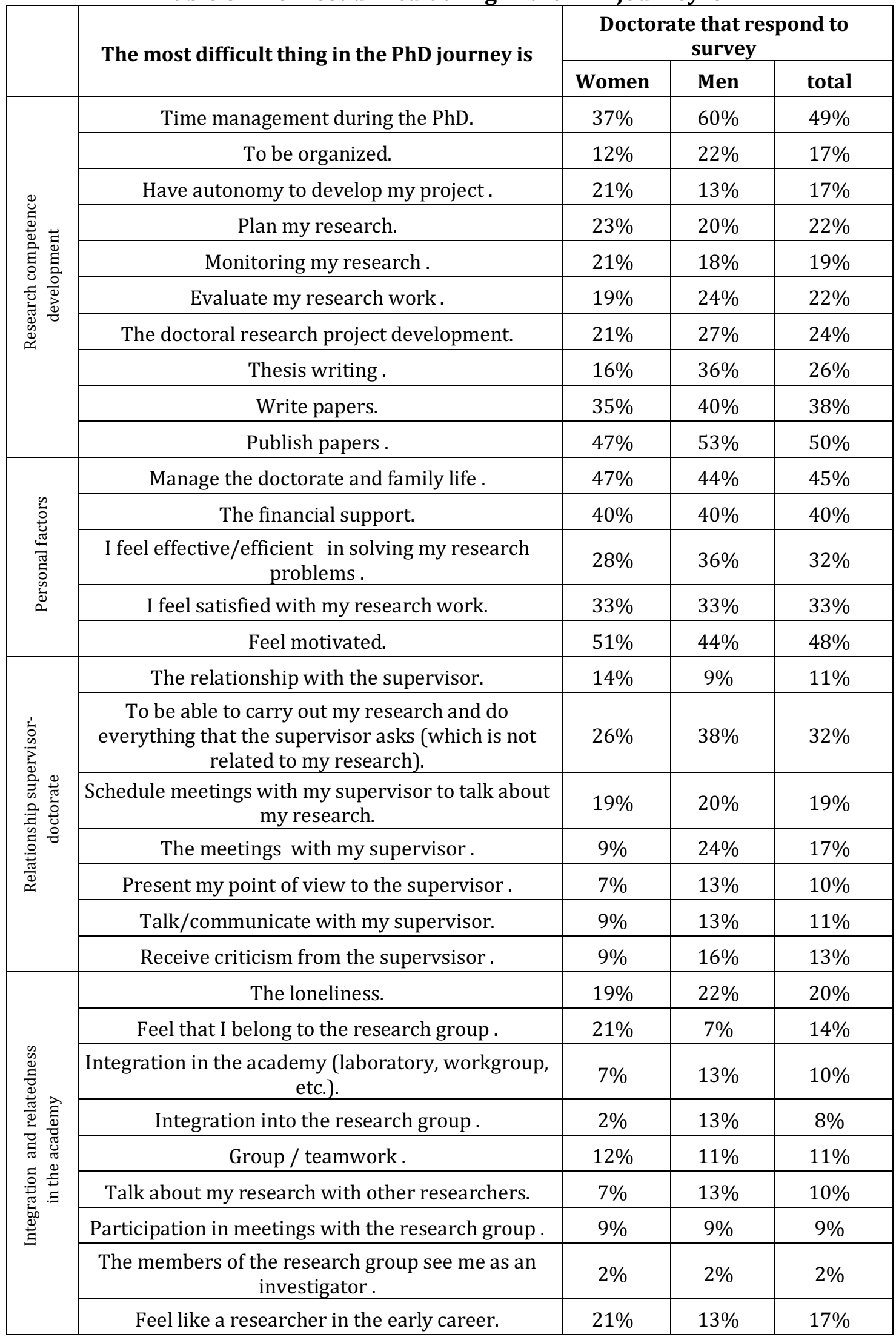


Concerning the relationship between doctorate and supervisor, a third of the respondents assign as one difficulty "To be able to carry out my research and do everything that the supervisor asks (which is not related to my research)", so supervisors' shouldn't overwhelm doctoral students with other tasks not related to the $\mathrm{PhD}$ research.

As regards the integration and relatedness in the academy it's possible to perceive that around twenty per cent of the respondents' doctorate feel loneliness. Similar data were found in previous research for UNL [Ribau, 2018, 2019 and 2020]. It is also important to highlight that twenty-one per cent of women don't feel that belong to a research group and are a researcher in their early career. Studying the factors that influence PhD candidates' success in the Netherlands, van Rooij, FokkensBruinsma, and Jansen (2019), concluded that "workload was negatively related to satisfaction and progress and positively to quit intentions". Masek (2020) but also David 2020 and Van Rooij and collaborators (2020) found that the quality of the supervisor-PhD candidate relationship was positively related to satisfaction and negatively to quit intentions. It should be emphasised that in a research published in 2019, by Helfer and Drew, they found that "the main reasons for dissatisfaction with supervision were identified as being the lack of involvement of supervisors in the research projects, particularly in the writing process, and the lack of supervisor's knowledge in the field being supervised."(Helfer\& Drew, 2019, p. 499)

Looking at data and considering gender, it is interesting to perceive that in our sample men had more difficulties managing time than women, but also regarding thesis writing. Considering the personal factors, the results are similar between men and women, but women felt more difficulties in being motivated. This item should be deeply understood, because it may be related not only to the family pressure (marriage, children's, and parents) but also with the academy pressure to complete the $\mathrm{PhD}$, the lake of support from family and supervisor, but also with the gender. The survey data indicate that the average age of these women is 30 years old and they face the problem of don't have employability in the Portuguese higher system (as a researcher and as a teacher) and the uncertainty of employment in the work market.

It is important to understand/capture if the difficulties were related to the enrolment time. To deepen these data, the data were processing considering three groups, the students that enrolled between 2011 and 2015 (average age of women 33 years old and men 35 years old), the doctorate that enrolled between 2016 and 2017 (average age of women 31 years old and men 33 years old) and the last one, the students that had their first enrolment between 2018 and 2019 (average age of women 27 years old and men 36 years old), table 9.

From the data, it is possible to perceive slight differences, Table 9. Considering gender age, it is interesting to perceive that women are younger than men considering the average age of each group, indicating that women start the PhD sooner than men. Analysing data groups 'is possible to perceive that women with the first enrolment in 2018-2019 are the youngest one, and the older are the women with the first enrolment between 2011 and 2015. The medium men age in all samples is between 33 and 36 and is not related to the time of the first enrolment.

Regarding research competence, women that had the first application between 20112015 and 2018-2019 have a similar percentage of difficulties related to writing and publishing papers. The men point out this difficulty in the group of the first enrolment between 2016 and 2017 and in the 
Coutinho, I. R. (2020 A (De)Formed Perception Of The Pathway To Be Taken During The P. hD. The Influence Of Time In The Students' Eyes Perception In Becoming A Researcher. Advances in Social Sciences Research Journal, 7(11) 272-308.

group enrolled for the first time in 2018 and 2019. Time management is more difficult for men than women, in all groups.

Regarding personal factors, women with the first enrolment during 2011-2015 and 2016-2017 consider that the most difficult thing in the $\mathrm{PhD}$ journey is to manage doctorate with family life $(50 \%$ and 53\% respectively) and 73\% of men enrolled for the first time in 2018-2019. Fell motivation is a difficulty more visible in women than in men (except the men in the youngest enrolment group). The lack of financial support is more highlighted in the oldest group of women, and this may be related to the end of scholarship/grant support that, in Portugal is given by "Fundação para a Ciência e Tecnologia" (which is an organism independent of the higher institution) usually implies 3 or four years of financial support and the payment of the $\mathrm{PhD}$ institution fees.

Regarding the relation with the supervisor, it is interesting that one of the most difficult things in the $\mathrm{PhD}$ journey assign by $25 \%$ or more the respondent doctoral students is "To be able to carry out my research and do everything that the supervisor asks (which is not related to my research". This may indicate that supervisors overwhelm students with tasks that aren't related to the $\mathrm{PhD}$ journey and that takes time to the PhD research development, which may be one reason for the attrition and lake of motivation, and this occurs in all groups.

Table 9. The most difficult thing in the PhD journey is...

\begin{tabular}{|c|c|c|c|c|c|c|c|c|}
\hline & \multirow{2}{*}{$\begin{array}{l}\text { The most difficult thing in the PhD } \\
\text { journey is }\end{array}$} & \multicolumn{2}{|c|}{\begin{tabular}{|c} 
First enrolment \\
year between \\
$2011-2015$ \\
\end{tabular}} & \multicolumn{2}{|c|}{$\begin{array}{c}\text { First enrolment } \\
\text { year between } \\
2016-2017 \\
\end{array}$} & \multicolumn{2}{|c|}{$\begin{array}{c}\text { First enrolment } \\
\text { year between } \\
2018-2019 \\
\end{array}$} & \multirow{2}{*}{\begin{tabular}{|c|}
$\begin{array}{c}\text { Regarding } \\
\text { all } \\
\text { students }\end{array}$ \\
$\begin{array}{c}\text { Total } \\
\text { average }\end{array}$ \\
\end{tabular}} \\
\hline & & Women & Men & Women & Men & Women & Men & \\
\hline \multirow{10}{*}{  } & Time management during the $\mathrm{PhD}$. & $33 \%$ & $56 \%$ & $47 \%$ & $50 \%$ & $29 \%$ & $73 \%$ & $49 \%$ \\
\hline & To be organized. & $8 \%$ & $13 \%$ & $18 \%$ & $20 \%$ & $7 \%$ & $36 \%$ & $17 \%$ \\
\hline & Have autonomy to develop my project & $17 \%$ & $6 \%$ & $29 \%$ & $15 \%$ & $14 \%$ & $18 \%$ & $17 \%$ \\
\hline & Plan my research. & $17 \%$ & $13 \%$ & $18 \%$ & $15 \%$ & $36 \%$ & $36 \%$ & $22 \%$ \\
\hline & Monitoring my research. & $25 \%$ & $13 \%$ & $12 \%$ & $5 \%$ & $29 \%$ & $45 \%$ & $19 \%$ \\
\hline & Evaluate my research work. & $25 \%$ & $19 \%$ & $6 \%$ & $15 \%$ & $29 \%$ & $45 \%$ & $22 \%$ \\
\hline & $\begin{array}{c}\text { The doctoral research project } \\
\text { development. }\end{array}$ & $17 \%$ & $13 \%$ & $18 \%$ & $25 \%$ & $29 \%$ & $45 \%$ & $24 \%$ \\
\hline & Thesis writing. & $25 \%$ & $44 \%$ & $18 \%$ & $20 \%$ & $7 \%$ & $45 \%$ & $26 \%$ \\
\hline & Write papers. & $42 \%$ & $25 \%$ & $24 \%$ & $45 \%$ & $43 \%$ & $45 \%$ & $38 \%$ \\
\hline & Publish papers. & $50 \%$ & $38 \%$ & $41 \%$ & $60 \%$ & $50 \%$ & $55 \%$ & $50 \%$ \\
\hline \multirow{6}{*}{ 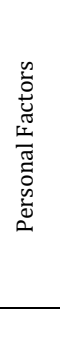 } & Manage the doctorate and family life. & $50 \%$ & $38 \%$ & $53 \%$ & $30 \%$ & $36 \%$ & $73 \%$ & $45 \%$ \\
\hline & The financial support. & $58 \%$ & $25 \%$ & $35 \%$ & $\mathbf{5 0 \%}$ & $29 \%$ & $36 \%$ & $40 \%$ \\
\hline & $\begin{array}{c}\text { I feel effective/efficient in solving my } \\
\text { research problems . }\end{array}$ & $42 \%$ & $38 \%$ & $12 \%$ & $35 \%$ & $36 \%$ & $27 \%$ & $32 \%$ \\
\hline & I feel satisfied with my research work. & $33 \%$ & $44 \%$ & $41 \%$ & $20 \%$ & $21 \%$ & $36 \%$ & $33 \%$ \\
\hline & Feel motivated. & $50 \%$ & $38 \%$ & $53 \%$ & $40 \%$ & $50 \%$ & $55 \%$ & $48 \%$ \\
\hline & The relationship with the supervisor. & $8 \%$ & $6 \%$ & $12 \%$ & $10 \%$ & $21 \%$ & $9 \%$ & $11 \%$ \\
\hline
\end{tabular}




\begin{tabular}{|c|c|c|c|c|c|c|c|c|}
\hline \multirow{6}{*}{ 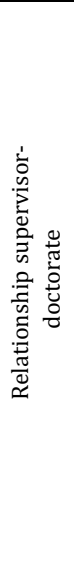 } & $\begin{array}{c}\text { To be able to carry out my research } \\
\text { and do everything that the supervisor } \\
\text { asks (which is not related to my } \\
\text { research). }\end{array}$ & $25 \%$ & $25 \%$ & $24 \%$ & $45 \%$ & $29 \%$ & $36 \%$ & $32 \%$ \\
\hline & $\begin{array}{l}\text { Schedule meetings with my supervisor } \\
\text { to talk about my research. }\end{array}$ & $17 \%$ & $31 \%$ & $24 \%$ & $15 \%$ & $14 \%$ & $9 \%$ & $19 \%$ \\
\hline & The meetings with my supervisor. & $0 \%$ & $38 \%$ & $12 \%$ & $20 \%$ & $14 \%$ & $9 \%$ & $17 \%$ \\
\hline & $\begin{array}{l}\text { Present my point of view to the } \\
\text { supervisor. }\end{array}$ & $8 \%$ & $13 \%$ & $6 \%$ & $15 \%$ & $7 \%$ & $9 \%$ & $10 \%$ \\
\hline & $\begin{array}{l}\text { Talk/communicate with my } \\
\text { supervisor. }\end{array}$ & $0 \%$ & $6 \%$ & $0 \%$ & $20 \%$ & $29 \%$ & $9 \%$ & $11 \%$ \\
\hline & Receive criticism from the supervsisor & $17 \%$ & $25 \%$ & $0 \%$ & $10 \%$ & $14 \%$ & $9 \%$ & $13 \%$ \\
\hline \multirow{9}{*}{ 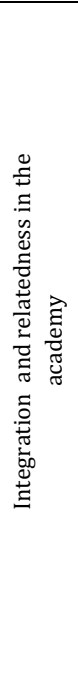 } & The loneliness. & $33 \%$ & $19 \%$ & $18 \%$ & $15 \%$ & $7 \%$ & $36 \%$ & $20 \%$ \\
\hline & $\begin{array}{l}\text { Feel that I belong to the research } \\
\text { group. }\end{array}$ & $33 \%$ & $0 \%$ & $18 \%$ & $5 \%$ & $14 \%$ & $18 \%$ & $14 \%$ \\
\hline & $\begin{array}{l}\text { Integration in the academy } \\
\text { (laboratory, workgroup, etc.). }\end{array}$ & $8 \%$ & $13 \%$ & $6 \%$ & $10 \%$ & $7 \%$ & $18 \%$ & $10 \%$ \\
\hline & Integration into the research group . & $8 \%$ & $6 \%$ & $0 \%$ & $15 \%$ & $0 \%$ & $18 \%$ & $8 \%$ \\
\hline & Group / teamwork. & $17 \%$ & $6 \%$ & $6 \%$ & $10 \%$ & $14 \%$ & $18 \%$ & $11 \%$ \\
\hline & $\begin{array}{l}\text { Talk about my research with other } \\
\text { researchers. }\end{array}$ & $17 \%$ & $6 \%$ & $0 \%$ & $15 \%$ & $7 \%$ & $18 \%$ & $10 \%$ \\
\hline & $\begin{array}{l}\text { Participation in meetings with the } \\
\text { research group. }\end{array}$ & $17 \%$ & $6 \%$ & $6 \%$ & $10 \%$ & $7 \%$ & $9 \%$ & $9 \%$ \\
\hline & $\begin{array}{c}\text { The members of the research group } \\
\text { see me as an investigator. }\end{array}$ & $8 \%$ & $6 \%$ & $0 \%$ & $0 \%$ & $0 \%$ & $0 \%$ & $2 \%$ \\
\hline & $\begin{array}{l}\text { Feel like a researcher in the early } \\
\text { career. }\end{array}$ & $25 \%$ & $6 \%$ & $6 \%$ & $25 \%$ & $36 \%$ & $0 \%$ & $17 \%$ \\
\hline
\end{tabular}

Concerning the integration in the academy, there is a feeling of loneliness in all groups, but also the feeling that they don't belong to the research group especially among women, which increase with the increase of the enrolment time. It should be mentioned that the group that feels more uncomfortable concerning the relation and meetings with the supervisor, is the women youngest one, decreasing with the enrolment time. For men, the meeting with the supervisor is a hard task and this difficulty increase with enrolment time.

The result may be understood considering that If they (supervisor-student) don't fit/match and the supervisor is not accessible to the students' needs, the students usually give up the degree or persist but have attrition. As Cornér, Löfström and Pyhältö (2017) found in their research "Experienced lack of satisfaction with supervision and equality within the research community and a low frequency of supervision were related (...) to students' attrition intentions. Attrition intentions were related to the source of supervision, the form of a thesis, and inadequate supervision frequency" (Cornér, Löfström \& Pyhältö, 2017, 91).

\section{PhD tasks}

To apprehend if the difficulties felt were related to the PhD tasks that students were doing at the moment of the survey application, a list of tasks was proposed in the questionnaire and students had to select what were they doing. To comprehend the impact of enrolment time for the perception 
Coutinho, I. R. (2020 A (De)Formed Perception Of The Pathway To Be Taken During The P. hD. The Influence Of Time In The Students' Eyes Perception In Becoming A Researcher. Advances in Social Sciences Research Journal, 7(11) 272-308.

of the PhD journey, the doctorate sample were grouped, in two sets, one with students in the first or second year of enrolment (if they were in partial time they were in the first year) with the first inscription between $2018-2019$ (27\% of the sample), and the others (73\%) with three or more years of enrolment. This way we had the doctorate perception at the beginning of the PhD journey, and the sensitivity of the doctorate with more experience in the PhD Journey, and the research needs regarding not only personal vicissitudes but also research project requirements. It was intended to perceive if the first years' of enrolment had specific tasks that differ from the other years, Table 10.

Table 10. What are you doing at this moment in your PhD journey?

\begin{tabular}{|c|c|c|}
\hline \multirow{3}{*}{ PhD journey task } & \multirow{2}{*}{\multicolumn{2}{|c|}{$\begin{array}{c}\begin{array}{c}\text { Percentage of students that are } \\
\text { doing the task }\end{array} \\
\text { First enrolment year } \\
\end{array}$}} \\
\hline & & \\
\hline & \begin{tabular}{|c|} 
between 2011- \\
2017 \\
\end{tabular} & $\begin{array}{l}\text { between 2018- } \\
2019 \\
\end{array}$ \\
\hline I am attending Doctoral Program classes . & $11 \%$ & $46 \%$ \\
\hline I am selecting and reading literature. & $19 \%$ & $42 \%$ \\
\hline I am building my research tools. & $9 \%$ & $46 \%$ \\
\hline I am planning my PhD research. & $17 \%$ & $46 \%$ \\
\hline I'm collecting data. & $42 \%$ & $67 \%$ \\
\hline I am doing data processing. & $38 \%$ & $42 \%$ \\
\hline I'm writing scientific papers. & $53 \%$ & $50 \%$ \\
\hline I am writing the thesis. & $27 \%$ & $0 \%$ \\
\hline $\begin{array}{l}\text { I am making corrections to the thesis } \\
\text { provisional versio }\end{array}$ & $2 \%$ & $0 \%$ \\
\hline $\begin{array}{l}\text { I have already delivered the provisional version } \\
\text { and I am waiting for the defense of the thesis } \\
\text { (VIVA voice). }\end{array}$ & $6 \%$ & $0 \%$ \\
\hline $\begin{array}{l}\text { I have already defended the thesis and I am } \\
\text { waiting to collect my diploma/Certificate. }\end{array}$ & $2 \%$ & $0 \%$ \\
\hline $\begin{array}{c}\text { I already complete the } \mathrm{PhD} \text { and,I am not doing } \\
\text { anything right now. }\end{array}$ & $2 \%$ & $0 \%$ \\
\hline Another situation & $2 \%$ & $0 \%$ \\
\hline
\end{tabular}

It is interesting to see that half the doctorate that started in the first period of analysis (enrolment between 2011 and 2017, which correspond to 73\% of the total doctorate sample) were writing scientific papers, $27 \%$ were writing the thesis, with $42 \%$ collecting and processing data. In the second period of analysis (students first enrolment between 2018 and 2019, which correspond to $27 \%$ of the doctorate sample) more than half (67\%) were collecting data, $50 \%$ writing papers, $46 \%$ planning and building the research tools and attending $\mathrm{PhD}$ course classes. Forty-two per cent were analysing/processing data and also selecting and reading literature. Only $35 \%$ of the respondent doctorate who have started their doctoral programs the longest time was in the last phases of the $\mathrm{PhD}$ journey (writing the thesis making corrections, waiting for VIVA Voice), but $53 \%$ were writing papers. 
The students that started in 2018 (who had been enrolled for at least two years in the doctorate) were building instruments, reading, planning the research, and writing papers. Seven doctoral students in this group were enrolled in part-time (data not shows).

Another perspective is the analysis considering the completion time of the $\mathrm{PhD}$, and grouping in two sets, the first one with students that started their enrolment between 20112015 (four years), and other considering that between 2016 and 2019 (three years), Table 11.

Table 11. What are you doing at this moment in your PhD journey?

\begin{tabular}{|c|c|c|}
\hline \multirow{2}{*}{ PhD journey task } & $\begin{array}{c}\text { Percentage of students that are doing } \\
\text { the task }\end{array}$ \\
\cline { 2 - 3 } & \multicolumn{2}{|c|}{ First enrolment year } \\
\cline { 2 - 3 } & $\begin{array}{c}\text { between 2011- } \\
\mathbf{2 0 1 5}\end{array}$ & $\begin{array}{c}\text { between 2016- } \\
\mathbf{2 0 1 9}\end{array}$ \\
\hline I am attending Doctoral Program classes & $8 \%$ & $26 \%$ \\
\hline I am selecting and reading literature. & $8 \%$ & $32 \%$ \\
\hline I am building my research tools & $4 \%$ & $26 \%$ \\
\hline I am planning my PhD research. & $4 \%$ & $34 \%$ \\
\hline I'm collecting data. & $27 \%$ & $\mathbf{5 8 \%}$ \\
\hline I am doing data processing. & $27 \%$ & $\mathbf{4 4 \%}$ \\
\hline I'm writing scientific papers. & $\mathbf{4 6 \%}$ & $\mathbf{5 5 \%}$ \\
\hline I am writing the thesis. & $\mathbf{4 6 \%}$ & $8 \%$ \\
\hline I am making corrections to the thesis provisional version . & $4 \%$ & $0 \%$ \\
\hline $\begin{array}{c}\text { I have already delivered the provisional version and I am } \\
\text { waiting for the defense of the thesis (VIVA voice). }\end{array}$ & $15 \%$ & $0 \%$ \\
\hline $\begin{array}{c}\text { I have already defended the thesis and I am waiting to } \\
\text { collect my diploma/Certificate. }\end{array}$ & $4 \%$ & $0 \%$ \\
\hline $\begin{array}{c}\text { I already complete the PhD and,I am not doing anything } \\
\text { right now . }\end{array}$ & $4 \%$ & $0 \%$ \\
\hline Another situation & $4 \%$ & $0 \%$ \\
\hline
\end{tabular}

It is important to highlight that, as was said before, in this Science and engineering school there are $\mathrm{PhD}$ courses that take three years to complete (the ideal time propose by the institution) and others that take four years to complete, being the average considering the weight of each course time 3,6 years. Although there are not institutional publish data related to attrition in the last years (Ribau \& Alves, 2017), it is possible to perceive (Table 11) that there is a delay in the $\mathrm{PhD}$ completion since only $27 \%$ of the doctorate, that start the enrolment between 2011 and 2015, in 2019 are in the final phases of the doctoral process (correcting the provisional thesis version, are waiting for VIVA or already have the degree) and $46 \%$ are writing the thesis.

At this point, it is relevant to remember that this analysis is based on a sample and not in the institution data, but shows that there is attrition. In this context, it's important to identify the reasons that, may cause attrition or delay in concluding the degree. This information can help to understand persistence, resilience and the drop out of the PhD students, and reinforce the support 
Coutinho, I. R. (2020 A (De)Formed Perception Of The Pathway To Be Taken During The P. hD. The Influence Of Time In The Students' Eyes Perception In Becoming A Researcher. Advances in Social Sciences Research Journal, 7(11) 272-308.

that leads students to continue in the PhD. PhD quality regarding the curriculum quality and the adequacy of the $\mathrm{PhD}$, from the doctorate point of view, was also analysed.

\section{PhD curriculum quality from the student's view}

The curriculum quality, from the PhD students' eyes, was assessed. Doctoral students had to classify some parameters related to support (supervisor, institution, and peers), curriculum design, and methodologies used as, very bad, bad, good or very good. One hypothesis was that the perceptions regarding the $\mathrm{PhD}$ quality change over time, not only because they are now facing the PhD journey, but because they start comparing their personal milestones with their achievements, Fig 4 and 5. The data were grouped in two sets, the first one with students that started their enrolment between 2018 and 2019 (in the first or second year of enrolment) (Fig. 4), and other group considering the first application between 2011 and 2017 (Fig. 5).

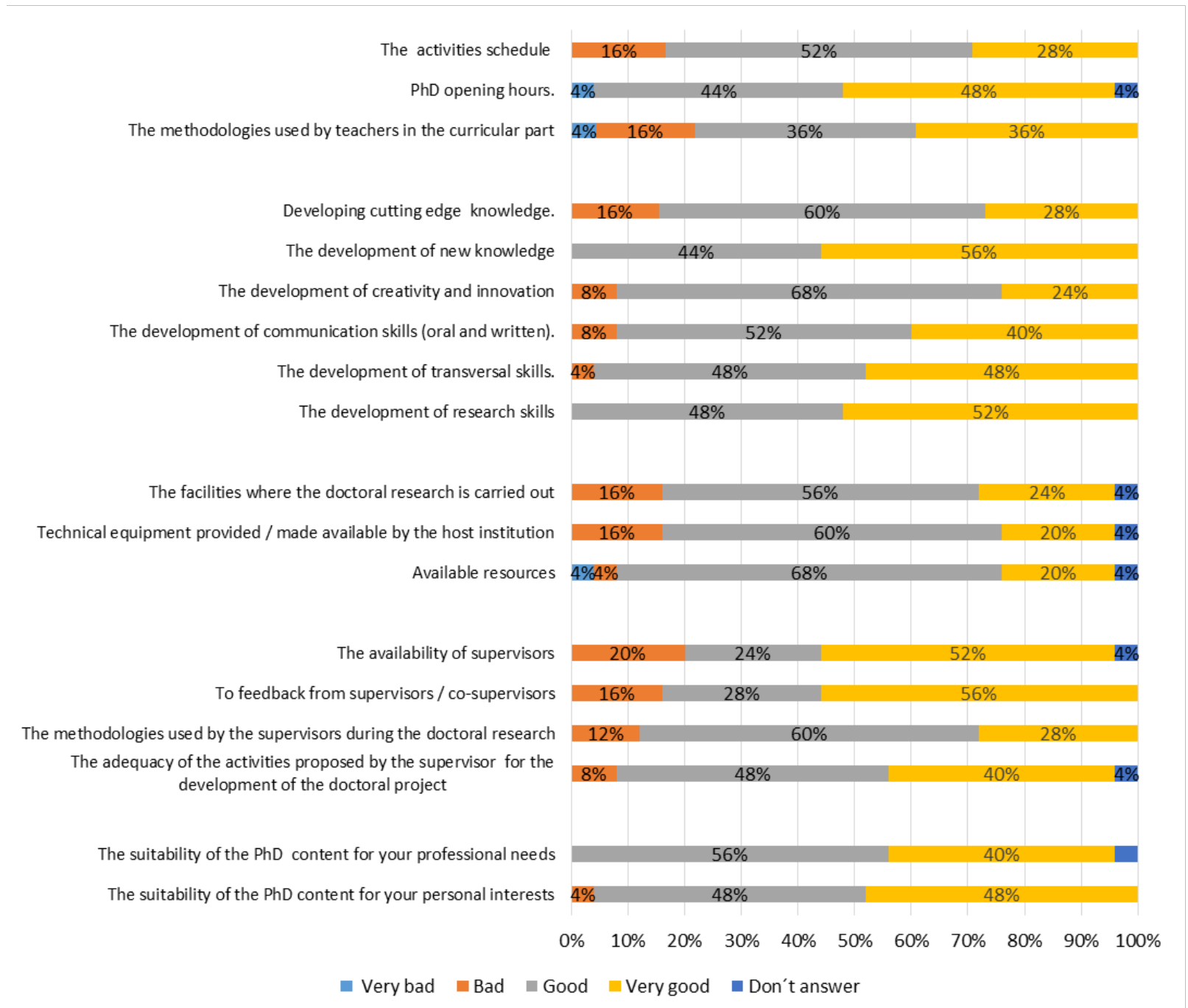

Figure 4. Perceptions of the doctoral students that had their first enrollment between 2018 and 2019 regarding PhD quality. 


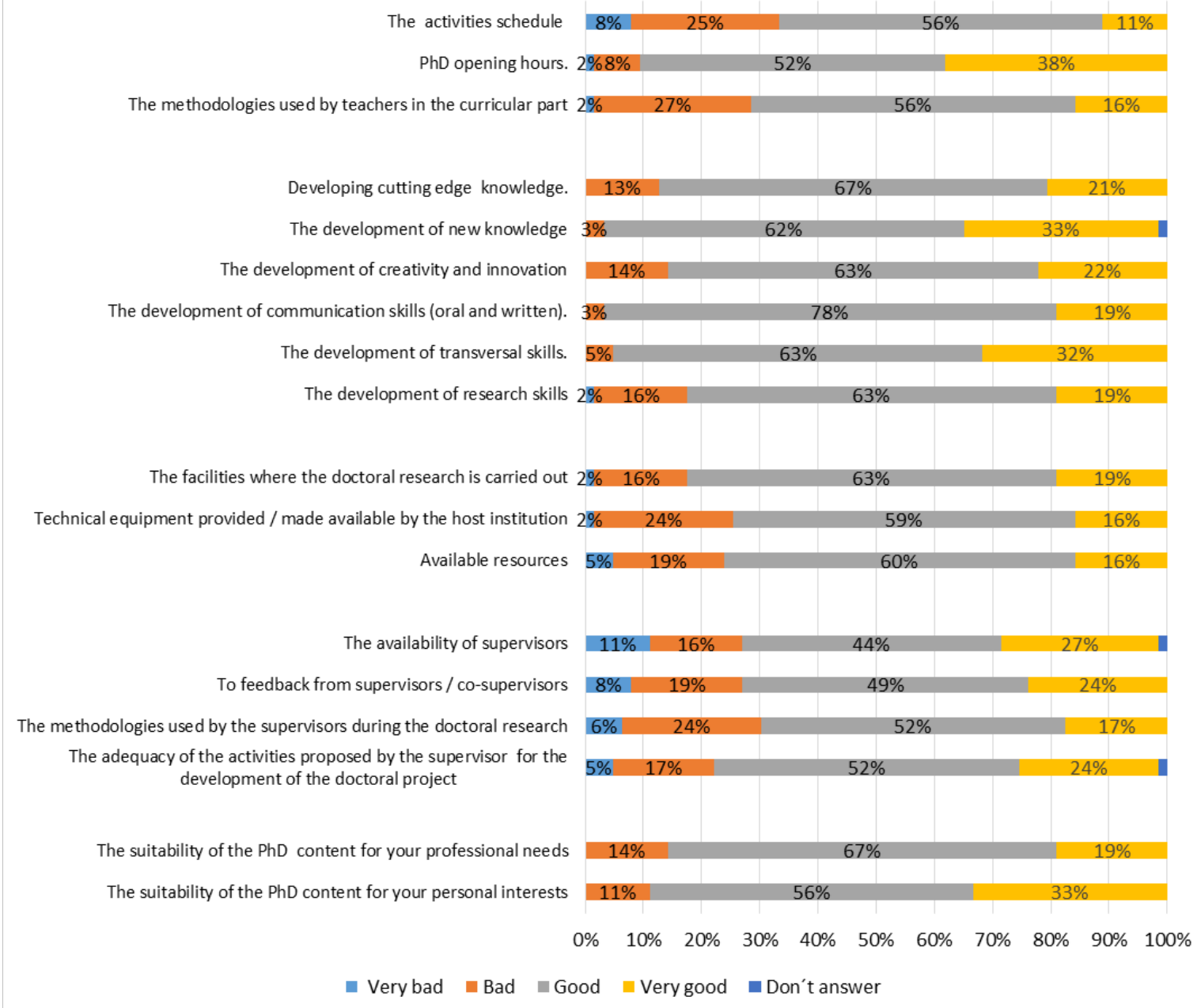

Figure 5. Perceptions of the doctoral students that had their first enrollment between 2011 and 2017 regarding PhD quality.

In pristine view, the "fresh" doctoral students have a positive view (more or than $80 \%$ of the respondents classify the goals with good or very good) of the adequacy of the PhD to the proposed goals. But some dissatisfaction emerges regarding the methodologies and activities schedule/timetable and opening hours, as 16\% consider that they are bad, Fig. 4.

Concerning the competence development during the time they were attending the PhD, all of the students point out that knowledge development and research skills development were good or very good. $16 \%$ assign that the adequacy of the PhD to develop a cutting edge Knowledge was bad. Only $16 \%$ of the doctorate in this group understand the institutional support as bad - the facilities and the equipment available were not adequate for the PhD research development, Fig.4. Regarding the supervision, for this group of doctoral students, the adequacy of the activities proposed by the supervisor for the development of the doctoral project and the supervisor availability were the items more negatively assign: twenty per cent of the students consider it the supervisor availability bad; $16 \%$ of the doctorate consider that the quality of the supervisor feedback is bad. It is important to highlight that, in this group, the adequacy of the PhD is suitable to the doctorate, professional needs (56\% indicate that is good and 40\% very good) and to personal needs (48\% indicate that is 
Coutinho, I. R. (2020 A (De)Formed Perception Of The Pathway To Be Taken During The P. hD. The Influence Of Time In The Students' Eyes Perception In Becoming A Researcher. Advances in Social Sciences Research Journal, 7(11) 272-308.

good and $48 \%$ very good). The degree of satisfaction of PhD students in the first and second year is high, concerning the suitability of the $\mathrm{PhD}$ for their personal and professional objectives and corresponds to their expectations. But this first year generally corresponds to a year in which students attend classes to reinforce and improve some skills necessary for the development of the $\mathrm{PhD}$ project, and they are only starting to emerge in the $\mathrm{PhD}$ routine.

Looking at the data (Fig.5) regarding the perception of the doctorate that is enrolled three years at least, it emerges a negative feeling related to quality and the adequacy of the $\mathrm{PhD}$ to some goals, Fig 5. The first three parameters are related to activities proposed during the $\mathrm{PhD}$ and methodologies used in the first year of enrolment classrooms. The dissatisfaction was presented by $25 \%-27 \%$ of the students' although the average of the responses was good, Fig. 5. Regarding the curriculum design and competences development, although we have all parameters with a classification of bad ranging between $3 \%$ and $16 \%$, it is possible to conclude that students generally consider that the adequacy of the PhD to the development of Skills and Knowledge was good.

Concerning the institution support and conditions, it is important to look to the numbers of doctoral students that identify, as bad or very bad the adequacy of the $\mathrm{PhD}$ facilities, equipment, and resources, because they are representative; they vary between $18 \%$ and $26 \%$ of the student who has been enrolled for the longest period. It is also important to look at the data regarding the opposite situation, with only $16 \%$ to $19 \%$ of the $\mathrm{PhD}$ students considering them very good. In this group, there are also negative perceptions regarding supervision and the supervisors' support. Regarding the supervisor availability $11 \%$ indicate that was very bad, and $16 \%$ that was bad. Regarding feedback, $8 \%$ identify it as very bad and $19 \%$ as bad. Methodologies use by supervisors were classified as very bad by $6 \%$ and bad by $24 \%$ of this doctorate sample. Considering the research development and the adequacy of the tasks proposed by the supervisor, $5 \%$ indicate that the tasks are very bad adequate and $17 \%$ that they are bad. This last evaluation and considering all five areas of analysis are the most negative one. So supervision may be a problem for these PhD students.

Looking data (Fig. 4 and Fig. 5) it should be noticed that doctoral students enrolled at the longest time (which have more years of $\mathrm{PhD}$ journey experience and are $73 \%$ of the survey respondents) have a more critical image of the PhD quality than the students that have less time of enrolment. The number of parameters assigns with very bad, ranging from 11 (Fig. 5) to 3 (Fig.4). The parameters assign with "bad adequacy" also increases with the enrolment time from 15 to 18 when we compare data in Fig. 4 with data in Fig. 5. The percentage of all parameter consign to "very good" decreases compared the perception of the doctorate between 2018 and 2019 with the students enrolled between 2011 and 2017 and the percentage of doctorate that classify the parameters with "bad" increase, Fig 4 and Fig.5. This change in perception, of the adequacy of the PhD curriculum design, institution, and supervisor support, from a positive to a more negative one, may reveal the disappointment of some doctoral students with the $\mathrm{PhD}$ journey, but also with the supervision quality. Almost all students are taking more time than is supposed to, which may lead to negative feelings and demotivation.

The support given by the institution, namely the resources, and supervisor methodologies and the proposed task was also a theme where the discontent increased (dissatisfaction with methodologies and approaches used during the doctoral research) from $12 \%$ to $30 \%$. The negative view of the 
adequacy of the activities proposed by the supervisor for the development of the doctoral project increase from $8 \%$ of the doctorate considering them bad to $22 \%$ (bad and very bad), but also the supervisors' feedback (with an increase from 16\% to 27\%) and availability increased from $20 \%$ (classification with bad) to $27 \%$ (considering the classification of bad and very bad). This increase in the negative view regarding the $\mathrm{PhD}$ quality may be related to the growing knowledge about the $\mathrm{PhD}$ journey, the operationalization of the PhD project, the PhD research development and a critical view of the activities/tasks proposed by the supervisor. These experiences/tasks may lead to a sense of waste-time (time that they usually don't have), and to the disappointment with the supervision and guidance of the $\mathrm{PhD}$ research.

\section{Degree of research development during the PhD from the student's view}

The knowledge regarding the development of competencies during the PhD journey and PhD quality was deepened. A list of research competence was present to the PhD students, who had to classify them regarding the degree of development during the PhD. So they had to indicate if they had developed to a great extent (deeply), developed considerably, were developing yet, were underdeveloped, or didn't develop at all. The Hypotheses were that "Doctoral students enrolled the longest time perceived them self's as person's o developed more deeply skills, than the youngest in the PhD journey", as they were engaged in the PhD longer time. The same group criteria used in the analysis of the PhD curriculum quality were also used here, to analyze the collected data: data were grouped in two sets: those who signed up for over two years (first application between 2011 and 2017) and those who signed up for the first time in 2018 or 2019, Table 12.

Table 12 Degree of research skills developed during the PhD from the students' point of view.

\begin{tabular}{|c|c|c|c|c|c|c|c|c|c|c|c|c|}
\hline \multirow[b]{2}{*}{$\begin{array}{c}\text { Degree of development during } \\
\text { the PhD from } \\
+ \text { AN5+P4:AB11+P4:AH14+P4: } \\
\text { AH15+P4+P4:AB17 }\end{array}$} & \multicolumn{6}{|c|}{$\begin{array}{l}\text { First enrolment year between } 2011 \text { and } \\
\qquad 2017\end{array}$} & \multicolumn{6}{|c|}{$\begin{array}{l}\text { First enrolment year between } 2018 \text { and } \\
\qquad 2019\end{array}$} \\
\hline & \begin{tabular}{|c} 
I \\
devel \\
oped \\
to a \\
great \\
exte \\
nt \\
(deelpl \\
y) \\
\end{tabular} & $\begin{array}{l}\text { I } \\
\text { develo } \\
\text { ped } \\
\text { conside } \\
\text { rably }\end{array}$ & $\begin{array}{c}\text { I'm } \\
\text { develo } \\
\text { ping }\end{array}$ & $\begin{array}{c}\text { under } \\
\text { devel } \\
\text { ope } \\
\mathrm{d} \\
\text { skill } \\
\mathrm{s}\end{array}$ & $\begin{array}{c}\text { I } \\
\text { didn' } \\
t \\
\text { dev } \\
\text { elop }\end{array}$ & $\begin{array}{c}\text { Not } \\
\text { resp } \\
\text { ond }\end{array}$ & $\begin{array}{c}\text { I } \\
\text { devel } \\
\text { oped } \\
\text { to a } \\
\text { great } \\
\text { exten } \\
t \\
\text { (deelpl } \\
\text { y) } \\
\end{array}$ & \begin{tabular}{|c} 
I \\
develo \\
ped \\
conside \\
rably
\end{tabular} & $\begin{array}{c}\text { I'm } \\
\text { develo } \\
\text { ping }\end{array}$ & $\begin{array}{c}\text { under } \\
\text { devel } \\
\text { ope } \\
\text { d } \\
\text { skill } \\
\text { s }\end{array}$ & $\begin{array}{l}\text { I } \\
\text { didn } \\
\text { 't } \\
\text { deve } \\
\text { lop }\end{array}$ & $\begin{array}{l}\text { Not } \\
\text { resp } \\
\text { ond }\end{array}$ \\
\hline $\begin{array}{l}\text { Skills/competencies to } \\
\text { analyze and synthesize }\end{array}$ & $23 \%$ & $52 \%$ & $23 \%$ & $2 \%$ & $0 \%$ & & $42 \%$ & $0 \%$ & $54 \%$ & $4 \%$ & $0 \%$ & \\
\hline $\begin{array}{l}\text { Skills/competence to apply } \\
\text { knowledge in practice }\end{array}$ & $41 \%$ & $28 \%$ & $27 \%$ & $5 \%$ & $0 \%$ & & $25 \%$ & $21 \%$ & $46 \%$ & $8 \%$ & $0 \%$ & \\
\hline $\begin{array}{c}\text { Knowledge in a specific } \\
\text { research area (Know-how) }\end{array}$ & $41 \%$ & $25 \%$ & $33 \%$ & $2 \%$ & $0 \%$ & & $25 \%$ & $21 \%$ & $46 \%$ & $8 \%$ & $0 \%$ & \\
\hline $\begin{array}{l}\text { Planning and time } \\
\text { management }\end{array}$ & $25 \%$ & $34 \%$ & $25 \%$ & $13 \%$ & $3 \%$ & & $25 \%$ & $17 \%$ & $46 \%$ & $8 \%$ & $0 \%$ & $4 \%$ \\
\hline $\begin{array}{l}\text { Ability to monitor my } \\
\text { research }\end{array}$ & $33 \%$ & $30 \%$ & $28 \%$ & $9 \%$ & $0 \%$ & & $13 \%$ & $29 \%$ & $54 \%$ & $4 \%$ & $0 \%$ & \\
\hline $\begin{array}{l}\text { Basic general knowledge in } \\
\text { the field of study }\end{array}$ & $36 \%$ & $38 \%$ & $25 \%$ & $2 \%$ & $0 \%$ & & $21 \%$ & $21 \%$ & $46 \%$ & $8 \%$ & $4 \%$ & \\
\hline $\begin{array}{l}\text { Knowledge of a second } \\
\text { language }\end{array}$ & $22 \%$ & $31 \%$ & $17 \%$ & $20 \%$ & $9 \%$ & & $13 \%$ & $4 \%$ & $42 \%$ & $29 \%$ & $8 \%$ & $4 \%$ \\
\hline
\end{tabular}


Coutinho, I. R. (2020 A (De)Formed Perception Of The Pathway To Be Taken During The P. hD. The Influence Of Time In The Students' Eyes Perception In Becoming A Researcher. Advances in Social Sciences Research Journal, 7(11) 272-308.

\begin{tabular}{|c|c|c|c|c|c|c|c|c|c|c|c|c|}
\hline $\begin{array}{c}\text { Capabilities/skills/competenc } \\
\text { ies of using simple software } \\
\text { (Word, Excel, etc.) }\end{array}$ & $23 \%$ & $23 \%$ & $13 \%$ & $25 \%$ & $\begin{array}{l}16 \\
\%\end{array}$ & & $17 \%$ & $4 \%$ & $42 \%$ & $25 \%$ & $\begin{array}{l}13 \\
\%\end{array}$ & \\
\hline $\begin{array}{l}\text { skills/competences of using } \\
\text { technical 'software' (use of } \\
\text { specific programs) }\end{array}$ & $38 \%$ & $25 \%$ & $23 \%$ & $13 \%$ & $2 \%$ & & $13 \%$ & $8 \%$ & $54 \%$ & $25 \%$ & $0 \%$ & \\
\hline $\begin{array}{c}\text { Research capabilities / } \\
\text { skills/skills }\end{array}$ & $38 \%$ & $28 \%$ & $28 \%$ & $6 \%$ & $0 \%$ & & $25 \%$ & $21 \%$ & $50 \%$ & $4 \%$ & $0 \%$ & \\
\hline $\begin{array}{c}\text { Learning skills / learning } \\
\text { strategies }\end{array}$ & $25 \%$ & $39 \%$ & $25 \%$ & $11 \%$ & $0 \%$ & & $13 \%$ & $38 \%$ & $50 \%$ & $0 \%$ & $0 \%$ & \\
\hline $\begin{array}{c}\text { Information management } \\
\text { skills }\end{array}$ & $22 \%$ & $39 \%$ & $28 \%$ & $11 \%$ & $0 \%$ & & $17 \%$ & $25 \%$ & $50 \%$ & $8 \%$ & $0 \%$ & \\
\hline \begin{tabular}{|c|} 
Critical thinking competences \\
and self-critical skills
\end{tabular} & $27 \%$ & $34 \%$ & $28 \%$ & $9 \%$ & $2 \%$ & & $17 \%$ & $25 \%$ & $50 \%$ & $8 \%$ & $0 \%$ & \\
\hline $\begin{array}{l}\text { Ability to adapt to new } \\
\text { situations }\end{array}$ & $42 \%$ & $25 \%$ & $23 \%$ & $9 \%$ & $0 \%$ & & $17 \%$ & $25 \%$ & $50 \%$ & $8 \%$ & $0 \%$ & \\
\hline \begin{tabular}{|c|} 
Ability to generate new ideas \\
/ knowledge
\end{tabular} & $30 \%$ & $31 \%$ & $30 \%$ & $9 \%$ & $0 \%$ & & $17 \%$ & $25 \%$ & $50 \%$ & $8 \%$ & $0 \%$ & \\
\hline Creativity & $27 \%$ & $22 \%$ & $31 \%$ & $20 \%$ & $0 \%$ & & $29 \%$ & $25 \%$ & $38 \%$ & $8 \%$ & $0 \%$ & \\
\hline Investigative autonomy & $45 \%$ & $27 \%$ & $20 \%$ & $8 \%$ & $0 \%$ & & $21 \%$ & $21 \%$ & $46 \%$ & $8 \%$ & $0 \%$ & $4 \%$ \\
\hline Problem solving skills & $38 \%$ & $20 \%$ & $34 \%$ & $6 \%$ & $2 \%$ & & $29 \%$ & $21 \%$ & $42 \%$ & $8 \%$ & $0 \%$ & \\
\hline $\begin{array}{c}\text { Competencies related to } \\
\text { decision making }\end{array}$ & $34 \%$ & $27 \%$ & $33 \%$ & $5 \%$ & $2 \%$ & & $21 \%$ & $25 \%$ & $46 \%$ & $8 \%$ & $0 \%$ & \\
\hline Work in an investigation team & $22 \%$ & $36 \%$ & $13 \%$ & $17 \%$ & $\begin{array}{l}11 \\
\%\end{array}$ & $2 \%$ & $21 \%$ & $17 \%$ & $50 \%$ & $8 \%$ & $4 \%$ & \\
\hline $\begin{array}{l}\text { Leadership skills / } \\
\text { competencies }\end{array}$ & $14 \%$ & $28 \%$ & $22 \%$ & $23 \%$ & $\begin{array}{l}13 \\
\% \\
\end{array}$ & & $4 \%$ & $29 \%$ & $46 \%$ & $8 \%$ & $\begin{array}{l}13 \\
\% \\
\end{array}$ & \\
\hline $\begin{array}{l}\text { Ability to work in an } \\
\text { interdisciplinary team }\end{array}$ & $25 \%$ & $39 \%$ & $13 \%$ & $14 \%$ & $8 \%$ & $2 \%$ & $13 \%$ & $25 \%$ & $54 \%$ & $8 \%$ & $0 \%$ & \\
\hline $\begin{array}{l}\text { Ability to communicate with } \\
\text { non-specialists }\end{array}$ & $11 \%$ & $41 \%$ & $17 \%$ & $28 \%$ & $2 \%$ & $2 \%$ & $13 \%$ & $25 \%$ & $46 \%$ & $13 \%$ & $4 \%$ & \\
\hline \begin{tabular}{|c|} 
Diversity and multiculturalism \\
valorization
\end{tabular} & $23 \%$ & $39 \%$ & $9 \%$ & $20 \%$ & $6 \%$ & $2 \%$ & $4 \%$ & $25 \%$ & $50 \%$ & $17 \%$ & $4 \%$ & \\
\hline $\begin{array}{l}\text { Ability to work in an } \\
\text { international context }\end{array}$ & $33 \%$ & $27 \%$ & $14 \%$ & $14 \%$ & $\begin{array}{l}11 \\
\% \\
\end{array}$ & $2 \%$ & $13 \%$ & $8 \%$ & $54 \%$ & $8 \%$ & $\begin{array}{l}17 \\
\%\end{array}$ & \\
\hline Ability to work autonomously & $48 \%$ & $23 \%$ & $19 \%$ & $8 \%$ & $2 \%$ & & $33 \%$ & $17 \%$ & $46 \%$ & $4 \%$ & $0 \%$ & \\
\hline Capability to design a project & $30 \%$ & $19 \%$ & $27 \%$ & $17 \%$ & $8 \%$ & & $13 \%$ & $25 \%$ & $50 \%$ & $8 \%$ & $4 \%$ & \\
\hline Skills to manage projects & $20 \%$ & $33 \%$ & $22 \%$ & $14 \%$ & $\begin{array}{l}11 \\
\%\end{array}$ & & $8 \%$ & $21 \%$ & $46 \%$ & $21 \%$ & $4 \%$ & \\
\hline $\begin{array}{c}\text { Initiative and entrepreneurial } \\
\text { thinking }\end{array}$ & $13 \%$ & $31 \%$ & $20 \%$ & $25 \%$ & $\begin{array}{l}11 \\
\% \\
\end{array}$ & & $8 \%$ & $25 \%$ & $46 \%$ & $17 \%$ & $4 \%$ & \\
\hline \begin{tabular}{|c|}
$\begin{array}{c}\text { Ability to innovate (think out } \\
\text { of the box) }\end{array}$ \\
\end{tabular} & $27 \%$ & $36 \%$ & $20 \%$ & $17 \%$ & $0 \%$ & & $21 \%$ & $13 \%$ & $46 \%$ & $17 \%$ & $4 \%$ & \\
\hline Ethical skills & $22 \%$ & $34 \%$ & $17 \%$ & $22 \%$ & $5 \%$ & & $21 \%$ & $25 \%$ & $33 \%$ & $17 \%$ & $4 \%$ & \\
\hline \begin{tabular}{|c|} 
Ability to deal with complex \\
problems (formulating \\
problems and proposing ways \\
to solve them)
\end{tabular} & $31 \%$ & $33 \%$ & $22 \%$ & $13 \%$ & $0 \%$ & $2 \%$ & $17 \%$ & $33 \%$ & $42 \%$ & $8 \%$ & $0 \%$ & \\
\hline
\end{tabular}




\begin{tabular}{|c|c|c|c|c|c|c|c|c|c|c|c|c|}
\hline \hline $\begin{array}{c}\text { Develop a broad (holistic) } \\
\text { view of the issues in order to } \\
\text { anticipate problems and } \\
\text { propose solutions }\end{array}$ & $20 \%$ & $47 \%$ & $20 \%$ & $11 \%$ & $2 \%$ & $8 \%$ & $29 \%$ & $50 \%$ & $13 \%$ & $0 \%$ & \\
\hline $\begin{array}{c}\text { Ability to put one's own ideas } \\
\text { into question (self-criticism) }\end{array}$ & $28 \%$ & $48 \%$ & $17 \%$ & $6 \%$ & $0 \%$ & $17 \%$ & $33 \%$ & $42 \%$ & $8 \%$ & $0 \%$ & \\
\hline $\begin{array}{c}\text { Ability to collaborate with } \\
\text { other doctoral students } \\
\text { (peers) and researchers }\end{array}$ & $34 \%$ & $\mathbf{3 9 \%}$ & $13 \%$ & $9 \%$ & $5 \%$ & $17 \%$ & $25 \%$ & $38 \%$ & $13 \%$ & $8 \%$ & \\
\hline Average & $29 \%$ & $32 \%$ & $22 \%$ & $13 \%$ & $4 \%$ & & $18 \%$ & $21 \%$ & $\mathbf{4 7 \%}$ & $11 \%$ & $3 \%$ & \\
\hline
\end{tabular}

In the group with the first enrollment between 2011 and 2017 although almost all skills were developed considerably (average 32\%) or deeply (average 29\%). In five items, 20\% to $41 \%$ doctorate, assigned that that skill was underdeveloped or not developed:

"Capabilities/skills/competencies of using simple software (Word, Excel, etc.)"; "Creativity"; "Leadership skills/ competence" (36\%); "Capability to design a project"; "Initiative and entrepreneurial thinking". It is important, at this point, emphasize that the competences, which $25 \%$ or more of the survey respondents indicate, that didn't develop or were underdeveloped (Table 12): "knowledge of a second language" (29\%); "Capabilities/skills/competencies of using simple software (Word, Excel, etc.)." (41\%); "Work in an investigation team" (28\%); "Leadership skills/competencies" (36\%); "Ability to communicate with non-specialists" (30\%); "Diversity and multiculturalism valorisation" (26\%); "Ability to work in an international context"(25\%); "Skills to manage projects" (25\%); Initiative and entrepreneurial thinking"(36\%); "Ethical skills" (27\%). This group gives us some clues regarding supervision and $\mathrm{PhD}$ curriculum development. It's important to note that these competencies are essential for a researcher and that the numbers are too high. It is not enough to have "good practice rules", the supervision must be rethought as it is and this implies monitorization and assessment by the institution.

Regarding the group with doctoral students enrolled between 2018 and 2019, considering all the $\mathrm{PhD}$ research skills that they should develop, an average of $47 \%$, considers that they are developing them, $21 \%$ assign that they already developed considerably, and an average of $18 \%$ have deeply developed them. Underlining the skills that $25 \%$ or more doctorates assign as underdeveloped or not developed at all, were "knowledge of a second language"; "Capabilities/skills/competencies of using simple software (Word, Excel, etc.)"; "Ability to work in an international context"; "Skills to manage projects". These underdeveloped skills are the same that were identified in the other group with almost the same percentage.

Organizing the data, considering only the skills/competence developed considerably or deeply viewed by the two groups, it is possible to distinguish three categories (Fig. 6): skills that have an increase of perception in the development of twenty or more per cent (above the blue line); skills that have an increase of perception in the development between the two groups and between $19 \%$ and $10 \%$ (between the blue and red line); skills that have an increase of perception lower than $10 \%$ (below the red line). 
Coutinho, I. R. (2020 A (De)Formed Perception Of The Pathway To Be Taken During The P. hD. The Influence Of Time In The Students' Eyes Perception In Becoming A Researcher. Advances in Social Sciences Research Journal, 7(11) 272-308.

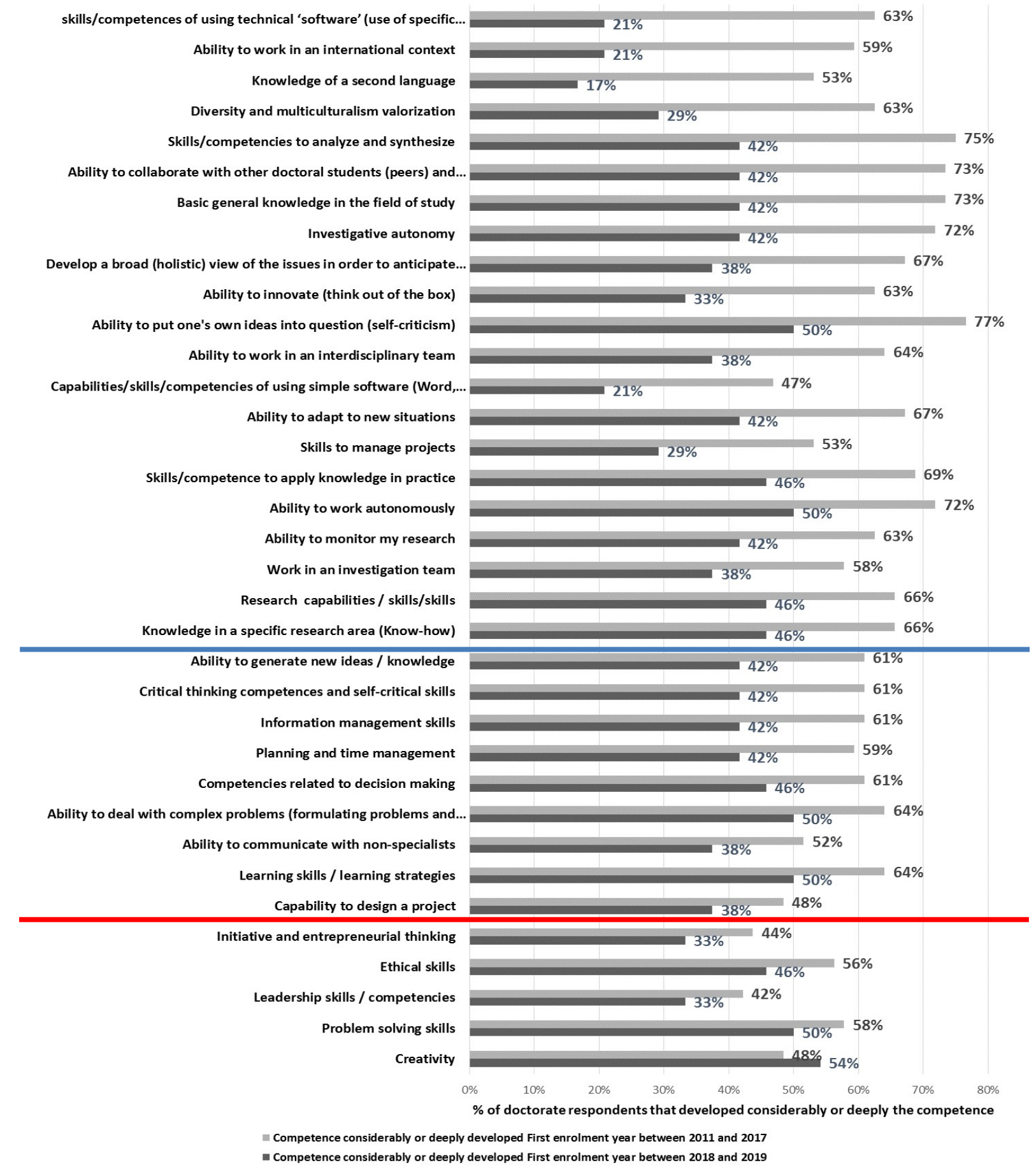

Figure 6. Degree of development during the PhD from the PhD students' point of view. Light grey Competence considerably or deeply developed - awareness of the students with the first enrolment year between 2011 and 2017; Grey - Competence considerably or deeply developed - awareness of

the students with the first enrolment year between 2018 and 2019. The competencies that are above the blue line have an increase in the perception of development equal to or greater than $20 \%$, comparing the data of the two groups. From the students' point of view, the competencies that are below this blue line had, an increase in the perception of development below $20 \%$. 
It is possible to perceive that the perception of development in almost all of the items increases from the youngest group to the group enrolled at more time, except creativity which has a decrease in the development perception.

The competencies that are above the blue line have an increase in the perception of development equal to or greater than $20 \%$, comparing the data of the two groups. The competencies that are below this line had an increase in the perception of development below $20 \%$ and they are the "ability to generate new ideas/knowledge", "Critical thinking and selfcritical skills", "information, plan and time management", "decision making competence", "the ability to deal with complex problems", and learning strategies/skills" which are related to creativity but also with leadership. Below the red line, the increase in the perception of development was below $11 \%$, and here are the skills related to being a leader: "Capability to design a project"; "Initiative and entrepreneurial thinking"; "Ethical skills" (related to the limits of experiments); "leadership competence"; "Problemsolving skills" and "creativity".

This may be related to the constraints of the PhD project regarding resources, equipment, time, independence, and autonomy. Because students may become autonomous (or have a sense of research independence) in applying technics and used equipment which gives them a false sense of autonomy, but they may not be autonomous in the PhD project guidance/development/plan as their new ideas/approach can be stopped - they depend on the approval of the supervisor. All of these barriers can lead to a sense of underdevelopment of creativity, as they feel constraints and a sense of urgency to finish the PhD. Looking to data it is possible to perceive that the perception of doctoral students regarding the development of Creativity is similar in both groups, Fig. 6. So time doesn't impact positively on their development and the percentage of doctoral students that refer their underdevelopment increases with time from $8 \%$ to $20 \%$.

From the 2008-2014 synthesis report entitled "Professional insertion pathway Graduates, masters and doctoral students from UNL", taken from the UNL page, http://www.unl.pt/sites/default/files /coorte_anual_-_sintese_2008-2014_-unl_15.2.pdf, retrieved on 1 Jun 2019), regarding the evaluation of doctorates, concerning the structuring training skills of the course, it reveals that there are some gaps regarding doctoral training. From this report, it is also possible to verify that 58.6\% of the doctorates are satisfied with the acquired professional skills, although it is verified that only $47.5 \%$ are very satisfied with the adequacy of doctoral courses to the demands of the labour market. On the other hand, doctorates reveal that in terms of theoretical knowledge the degree of satisfaction increases (65.7\% are very satisfied). PhDs perceive the deep knowledge in their area as a benefit for their profession, the ability to solve problems, question themselves, reflect and seek solutions as an added value for themselves.

However, the fact that they have not developed relational skills such as knowing how to work in a team / manage conflicts/work cooperatively and collaboratively is perceived as a gap in their doctoral preparation. Teamwork requires that employees have relational skills, know how to interact, make decisions, work under pressure, take responsibility and produce, and this is the opposite of what the doctorate does during the $\mathrm{PhD}$, where they often work alone, not developing these skills. Similar conclusions were found in the research work developed in the scope of the PhD in Educational Sciences at UNL, where PhD students said that teamwork and interpersonal skills are poorly developed (according to the perception of the PhD students). For the authors of this 
Coutinho, I. R. (2020 A (De)Formed Perception Of The Pathway To Be Taken During The P. hD. The Influence Of Time In The Students' Eyes Perception In Becoming A Researcher. Advances in Social Sciences Research Journal, 7(11) 272-308.

investigation, it is urgent to look at this data to fill or minimize this gap (Alves, Neves, Azevedo \& Gonçalves, 2012). The doctoral students also perceive as weaknesses of this $\mathrm{PhD}$, the development of leadership skills/competencies (Alves \& Azevedo, 2010). Taking into account the data of this research work and the data of the document "Professional insertion path Graduates, masters, and doctoral students" from UNL, this gap may be transversal to all doctoral programs. It should be noted that the doctoral course is generally an individual and sometimes solitary course, and, if the supervisor does not create moments of group interaction, may lead to isolation and nondevelopment of skills related to collaborative and cooperative work.

Time and project management is another factor where doctoral students feel they have a deficit in their training given the demands of their professional activity. This may be related to the lack of mechanisms for monitoring, checking, and planning the project during the doctoral course. Concluding, the gap described in the 2008-2014 synthesis report entitled "Professional insertion pathway Graduates, masters and doctoral students from UNL", taken from the UNL (http://www.unl.pt/sites/default/files/coorte_anual_-_sintese_2008-2014_-unl_15.2.pdf) and in the research work of Alves et al. (2012), still exist and is found in the present work.

\section{Supervisor qualities}

Considering that supervisors are the link to the institution and the doctoral student support, a question emerges: What was the degree of importance on supervisors of some characteristics regarding supervision competence (teaching, research knowledge, etc.) and some psychological attributes of them, Table 13.

Analysing data (Table 13), it is possible to perceive that supervisor competence regarding planning the supervision is very important for these doctoral students, but also research methodologies knowledge ( $62 \%$ of the doctorate considered it very important).

Supervisory skills regarding the doctoral teaching and learning process are highlighted as "Collaborate with doctoral students in solving research problems" is considered very important by $63 \%$ of the respondents as "Be open to new ideas " which is considered very important by $61 \%$ of the doctorate. Monitoring and follow-up the doctoral research by the supervisor are not understood as very important (the average of the three indicators is $42 \%$ ). But the monitorization of the research development is fundamental for meeting deadlines, achieve goals and learn to manage time/tasks, and complete the $\mathrm{PhD}$ in time. Deadlines are important as they usually are linked to milestones and to achieve goals. This low importance value may explain in part the attrition in some cases, as the student and supervisor don't put limits to complete the tasks, don't accompany students in the daily-work and delay and procrastination may occur as a result. 
Table 13. Degree of the importance of this characteristic in a supervisor...

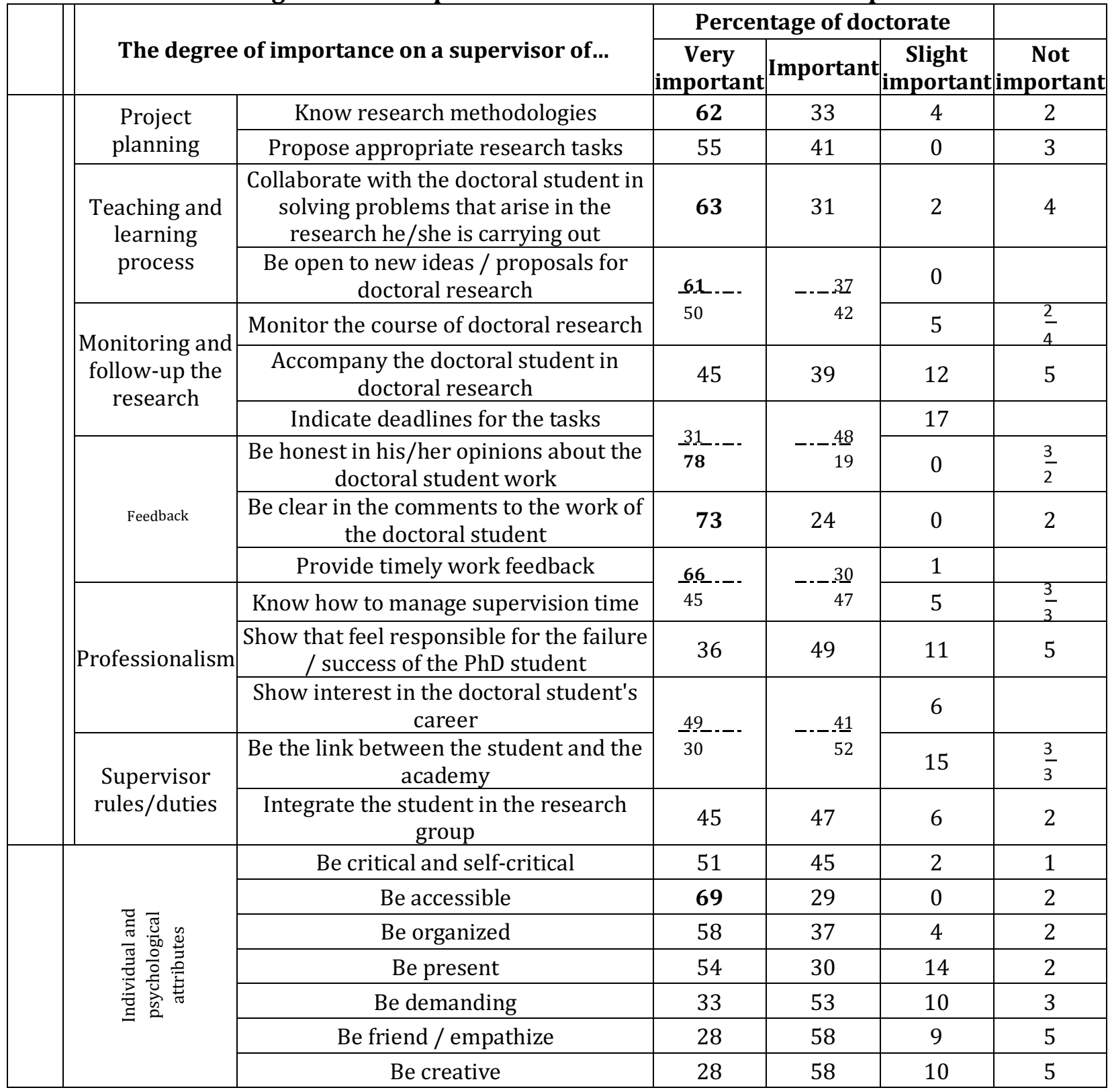

But the most important feature of a supervisor, for these doctoral students, is feedback (the three indicators have an average of $72 \%$ which emphasizes it). "Be honest in his/her opinion about the doctoral student work" (78\% consider this very important); "Be clear in the comments to the doctoral student research work". "Provide timely feedback" is assigned by sixty-six per cent of the respondents. It should be emphasized that these are the rules of good feedback (Kumar, Stracke, 2007; Stracke, Kumar, 2010). Similar to these research results, Woolderink, Putnik, van der Boom and Klabbers also found out in their research that "PhD candidates consider responsiveness and respectful, good-quality feedback by supervisors important (...)” (Woolderink, Putnik, van der Boom \& Klabbers, 2015). 
Coutinho, I. R. (2020 A (De)Formed Perception Of The Pathway To Be Taken During The P. hD. The Influence Of Time In The Students' Eyes Perception In Becoming A Researcher. Advances in Social Sciences Research Journal, 7(11) 272-308.

Supervisor rules/duties regarding supervision do not stand out as very important for these doctoral students. However, the supervisor must be the link between the student, the research group, and the academy. Only then will the student be included/integrated and socialized in the field of knowledge and academy but also be recognized by peers.

Considering the "ideal" supervisor psychological attributes "Be accessible" is assigned as very important by $69 \%$ of the respondents, following by "Be organized" ( $58 \%$ ascribe as very important ), "Be present" (54\% point to as very important) and be critical and self-critical (51\%).

\section{CONCLUSION}

In this research, it was possible to perceive that the career progression is the most important reason to apply for a $\mathrm{PhD}$, but personal reasons are relevant when we look the first phase of the PhD, the candidacy. Over time the reasons that lead a doctoral student to continue to be involved in the doctorate become essentially professional. The motives that lead a doctoral student to complete his doctorate are professional and economic. These changes in perspective may be linked to the maturity of the students, but also their perspective about everyday life and PhD experience. Good remuneration is linked to a better quality of life and as a recompense of all difficulties, which may be important in the balance between dropping out of the doctorate or persisting, fighting against adversities (lack or difficulties of financing; manage the family life, the doctorate and sometimes a job/work; to carry out their research but also others tasks that supervisor ask and that aren't related to the $\mathrm{PhD}$ project) and concluding the $\mathrm{PhD}$, even if it takes longer than originally planned. In conclusion, theirs a change from personal reasons to personal utility in taking a PhD.

Almost half of the students in the first or second year of enrolment are in the first phase of the doctoral journey (Fig.1); they are attending classes, selecting and reading literature, making/choosing the research tools/methodologies. More than half are collecting data (67\%, table 5 ) and half is writing papers which indicate that they are entering the $2^{\text {nd }}$ phase of the doctoral process. From the data (Table 10) is also possible to see that although $46 \%$ of the students that enrolled for the first time between 2011 and 2015 are written paper and the doctoral thesis, 4\% are making the thesis corrections, $15 \%$ already delivered the thesis $4 \%$ are waiting for the VIVA VOICE and $4 \%$ already completed the PhD. This means that almost $50 \%$ are at the end of the second phase of the research process and $27 \%$ of them are in the final phase of the process.

The hypothesis that the perceptions regarding the PhD curriculum quality change over time were confirmed. The doctoral students enrolled the longest time had a more negative perspective of the $\mathrm{PhD}$ quality than the younger ones in the $\mathrm{PhD}$ journey and the number of quality indicators viewed as a very bad increase and the indicators with the percentage of classification named "very good" decreased. The most relevant parameters/ indicators are the Supervisor availability, feedback, used methodologies and adequacy of the tasks to the aims of the PhD project. The suitability of the curriculum to professional needs and personal interests are also viewed as more negative (see Fig. 4 and 5).

The perceptions regarding the competencies developed change over time confirmed the hypotheses that "The doctoral students enrolled the longest time perceived them self's as a person's who developed more deeply skills than the youngest in the PhD journey", but there is an exception - the perception of developing creativity, Fig. 6. Almost half of the youngest group (first application in 
2018 and 2019) has the perception that they are developing skills, which reflects the hope in the curriculum and PhD. This should lead to change PhD curriculum to a more suitable one and improved and adjust it to the reality and the doctorate necessity.

Several guidelines have emerged in recent years, from the European Commission and associations of higher education institutions, like League of European Research Universities (LERU) and the European University Association (EUA), for doctoral education regarding the institutional role, supervisory practices, and role but also PhD students' journey and expectations regarding the enrolment in a doctorate. But also governments reflected about their policy concern the doctoral education (importance, goals, financial support, impact on society, and so one), is an important milestone, the Lisbon strategy (2000) that emphasize the third cycle as the bridge between research area and higher education area, as also the Salzburg Principles I (2005) and the Salzburg Principles II (2010), among others.

The changes proposed are reflected in the role and nature of supervision, and demand efficient use of technology, interpersonal relationship management, changes in the doctoral program not only in their modalities, structure, content, and design but also in different types regarding their goals (Park, 2005; Fillery-Travis, A., Maguire, K., Pizzolatti, N., Robinson, L., Lowley, A., Stel, N., \& Lee, A., 2017), which implies adjustments in practice, tasks, and training of doctoral research. It is important to highlight that, "Economically, large amounts of money are spent by institutions to recruit doctoral students, and once doctoral students are admitted institutions often pay for their tuition in exchange for student assistantships (Gardner, 2009). This money is essentially lost if the student does not complete the degree program." (Breitenbach, 2019). Have this in mind, the research data continue to confirm the difficulties felt by students to complete the degree (Ribau \& Alves, 2017 and 2018; Castell, Pardo, Sala-Bubare, \& Sune-Soler, 2017; Sverdlik, Hall, McAlpine \& Hubbard, 2018; Fillery-Travis, Maguire, Pizzolatti, Robinson, Lowley, Stel \& Lee, 2017; Breitenbach, 2019). Successful doctoral training involves the development of different areas and is a complex multitask journey, Fig. 1. As Chakraverty (2020) refers "Successful graduate training involves developing higher-order thinking/reasoning and scientific communication skills that are rather complex (Lovitts, 2005) and require psycho-social support, the integration in the academy and the sense of belonging but also and supervisor support" (Chakraverty, 2020). Dealing with self and the other's expectation (family, supervisor, academy among others) can be challenging for doctoral student's mental health, as the relation with the supervisor or team supervisors during the research training (Burt, Knight, \& Roberson, 2017; Evans, Bira, Gastelum, Weiss \& Vanderford, 2018; Chakraverty, 2020;). During the PhD, researchers are formed, and they can be developers, innovative and creative - a doctorate should think "out of the box" but also "inside the box".

These characteristics must be developed during the doctorate when the researcher is constructed, based on frontier knowledge, research competences as creativity, originality, innovation, and critical thinking, but also in leadership versus teamwork, independence, autonomy (Baptista, Frick, Holley, Remmik, Tesche, Âkerlind, 2015; Durette, Fournier \& Lafon, 2016; Maguire, \& Delahunt, 2017; Helfer \& Drew, 2019) and all of these with the constraints that appear during the development of the research process [Medeiros, Watts \& Mumford, 2017]. So it is important to perceive if the academic training given by the supervisor will shape the future researcher, as a follower or as an innovator. But, time to "produce" an executor is shorter than the time to "produce" 
Coutinho, I. R. (2020 A (De)Formed Perception Of The Pathway To Be Taken During The P. hD. The Influence Of Time In The Students' Eyes Perception In Becoming A Researcher. Advances in Social Sciences Research Journal, 7(11) 272-308.

an innovator, so the tendency of the supervisors is generally too opted for the first one (Baptista, et al., 2015). Then the knowledge construction is hindered and the innovations don't happen.

Although the data present in this study didn't allow the deepness of students' experience, the students' experience was developed in the survey and they will be published sooner.

\section{Limitation}

The number of doctoral students that respond to the survey doesn't allow a real characterization of the PhD population do the FCT-UNL. The survey did not deepen on the themes, but allow a general view of the doctoral students' perception regarding the candidacy and the intentions to complete the $\mathrm{PhD}$ and the difficulties they face during the $\mathrm{PhD}$.

\section{References}

Ăkerlind, G. \& McAlpine, L. (2017). Supervising doctoral students: Variation in purpose and pedagogy. Studies in Higher Education, Routledge 42, 1686-1698.

Abdullah, M. \& Evans, T. (2012). The relationships between postgraduate research students "psychological attributes and their supervisors" supervision training. Procedia - Social and Behavioral Sciences, 31, 788-793.

Alves, M, Azevedo, N. (2010). Third-Cycle Studies in Educational Sciences: expectations and competences development. European Educational Research Journal, 9, 69-81.

Alves, M., Neves, C., Azevedo, N., Gonçalves, T. (2012). Reconstructing Education? The Case of Master's and PhD Programmes in Education in a Portuguese Institution. European Educational Research Journal, 11, 520-534.

Baptista, A., Frick, L., Holley, K., Remmikd, M., Tesche, j. \& Âkerlind, G. (2015). The doctorate as an original contribution to knowledge: Considering relationships between originality, creativity, and innovation.

Frontline Learning Research Vol.3 No. 3 Special Issue (2015) 55 - 67 ISSN 2295-3159

Baptista, A. \& Huet, I. (2012). Making sense of metaphors about doctoral students' competencies: analysis of supervisors' voices. Procedia - Social and Behavioral Sciences, 47, 930-937.

Baptista, A. (2015). Mature students' voices on the ideal and reality of doctoral supervisors' role and practice. Procedia - Social and Behavioral Sciences, 191, 1544-1551.

Bastalich, W. (2017). Content and context in knowledge production: a critical review of doctoral supervision literature, Studies in Higher Education, 42, 1145-1157.

Blaj-Ward, L. (2011). Skills versus pedagogy? Doctoral Research training in the UK arts and Humanities. Higher Education Research \& Development, 30, 697-708.

Breitenbach, E. (2019). Evaluating a model to increase doctorate program completion rates: A Focus on Social Connectedness and Structure. International Journal of Doctoral Studies, 14, 217-236. https://doi.org/10.28945/4239

Burt, B. A., Knight, A., \& Roberson, J. (2017). Rationalizing experiences of foreign-born and ethnically diverse Black male engineering graduate students: Implications for student affairs practice, policy, and research. Journal of International Students, 7(4), 925-943. https://doi.org/10.32674/jis.v7i4.182

Castelló, M., Pardo, M., Sala-Bubare, A., \& Sune-Soler, N. (2017). Why do students consider dropping out of doctoral degrees? Institutional and personal factors. Higher Education, 74(6), 1053-1068. https://doi.org/10.1007/s10734016-0106-9

Chakraverty, D. (2020). PhD student experiences with the impostor phenomenon in STEM. International Journal of Doctoral Studies, 15, 159-179.https://doi.org/10.28945/4513.

Clarence, S. (2020). Making visible the affective dimensions of scholarship in postgraduate writing development work. Journal of Praxis in Higher Education, 2, 46-62. 
Cornér, S., Löfström, E., Pyhälto, K. (2017). The relationships between doctoral students' perceptions of supervision and burnout. International Journal of Doctoral Studies, 12, 91-106.

Coutinho, S. (2007). The relationship between goals, metacognition, and academic success. Educate, 7, 39-47.

David, J. (2020). Assessment matters: some issues concerning the supervision and assessment of workbased doctorates. Innovations in Education and Teaching International, 42, 87-92, Doi:10.1080/14703290500048994.

Davis, D. (2019). Students' perceptions of supervisory qualities: What do students want? What do they believe they receive? International Journal of Doctoral Studies, 14, 431-464.

https://doi.org/10.28945/4361

De Clercq, M., Devos, C., Azzi, A., Frenay, M., Klein, O. \& Galand, B. (2019). I need somebody to lean on.

The effect of peer, relative, and supervisor support on emotions, perceived Progress, and persistence in

Different stages of doctoral advancement. Swiss Journal of Psychology. 13. https://doi.org/10.1024/1421-0185/a000224

Denis, C., Colet, N. \& Lison, C. (2019). Doctoral Supervision in North America: perception and Challenges of Supervisor and supervisee. Higher Education Studies, 9, 30-39.

Durette, B., Fournier, M., \& Lafon, M. (2016). The core competencies of PhDs. Studies in Higher Education,

41(8), 1355-1370. https://doi.org/10.1080/03075079.2014.968540

Evans, T. M., Bira, L., Gastelum, J. B., Weiss, L. T., \& Vanderford, N. L. (2018). Evidence for a mental health crisis in graduate education. Nature Biotechnology, 36(3), 282. https://doi.org/10.1038/nbt.4089.

Figueiredo, C., Huet, I. \& Pinheiro, M. (2012). Construction of scientific knowledge and meaning: perceptions of Portuguese doctoral students. Procedia - Social and Behavioral Sciences, 69, 755-

Fillery-Travis, A. \& Robinson, L. (2018). Making Familiar strange - a research pedagogy for practice. Studies in Higher Education, 43, 841-853.

Fillery-Travis, A., Maguire, K., Pizzolatti, N., Robinson, L., Lowley, A., Stel, N., \& Lee, A. (2017). Insights from practice: A handbook for supervisors of modern doctorate candidates. Super Prof Doc.

Gardner, S. (2007). I heard it through the grapevine. Doctoral student socialization in chemistry and history. Higher education, 54, 723-740.

Gardner, S. (2008). Fitting the model of graduated school: a quantitative study of socialization in doctorate education. Innovations in Higher Education, 33, 125-138.

Gardner, S. (2008a). "What's too much and what's too little?" The process of becoming an independent research in doctoral education. The Journal of Higher Education, 79, 326-350.

Gardner, S. (2009). Student and faculty attributions of attrition in high and low-completing doctoral programs in the United States. High Educ, 58, 97-112.

Gardner, S. (2010). Faculty perspectives on doctoral student socialization in five disciplines. International Journal of Doctoral Studies, 5, 39-53.

Golde, C. (1998). Beginning graduate school: explaining first-year doctoral attrition. New directions for higher Education, 101, 55-64.

Golde, C. (2007). Signature Pedagogies in Doctoral Education: Are They Adaptable for the Preparation of Education Researchers? Educational Researcher, 36, 344-351. DOI: 10.3102/0013189X07308301

Helfer, F., \& Drew, S. (2019). Students' perceptions of doctoral supervision: A study in an engineering program in Australia. International Journal of Doctoral Studies, 14, 499-524.

https://doi.org/10.28945/4368 
Coutinho, I. R. (2020 A (De)Formed Perception Of The Pathway To Be Taken During The P. hD. The Influence Of Time In The Students' Eyes Perception In Becoming A Researcher. Advances in Social Sciences Research Journal, 7(11) 272-308.

Hermita, M. \& Thamrin, W. (2015). Metacognition toward academic self-efficacy among Indonesian private university scholarship students. Procedia - Social and Behavioral Sciences, 171, 1075-1080.

Holbrook, A., Shaw, K., Scevak, J., Bourke, S., Cantwell, R., \& Budd, J. (2014). PhD candidate expectations: Exploring mismatch with experience. International Journal of Doctoral Studies, 9, 329-346.

Hum, G. (2015). Workplace during the science doctorate: What influences research learning experiences and outcomes? Innovations in Education and Teaching International, 52, 29-40.

Humphrey, R., Marshall, N. \& Leonardo, L. (2012). The impact of research training and research codes of practice on submission of doctoral degrees: an exploratory cohort study. Higher Education Quarterly, 66, 47-64.

Hunter, K. \& Devine, K. (2016). Doctoral students' emotional exhaustion and intentions to leave academia. International Journal of doctoral studies, 11, 35-61.

Jones, M. (2013). Issues in doctoral studies-Forty years of journal discussion: Where have we been and where are we going? In Proceedings of the Informing Science and Information Technology Education Conference (pp. 83-104). Informing Science Institute. https://doi.org/10.28945/1859

Kamler, B. (2008). Rethinking doctoral publication practices: writing from and beyond the thesis. Studies in Higher Education, 33, 283-294.

Kleijn, R., Mainhard, T., Meijer, P., Pilot, A. \& Brekelmans, M. (2012). Master's Thesis supervision: relations between perceptions of the supervisor-student relationship, final grade, perceived supervisor contribution to learning and student satisfaction. Studies in Higher Education, 37, 925-939.

Kumar, V. \& Stracke, E. (2007). An analysis of written feedback on a PhD thesis. Teaching in Higher Education, 12, 461-470.

Maguire, M., \& Delahunt, B. (2017). Doing a thematic analysis: A practical, step-by-step guide for learning and teaching scholars. All Ireland Journal of Teaching and Learning in Higher Education, 9(3), 3351-3365.

Masek, A. (2020). A Review of Effective Doctoral Supervision: What Is It and How Can We Achieve It?

Universal Journal of Educational Research 8(6):2493-2500.DOI: 10.13189/ujer.2020.080633

Medeiros, K., Watts, L. \& Mumford, M. (2017). Thinking inside the box: Educating leaders to manage constraints. Handbook of Research on Creative Problem-Solving Skill Development in Higher Education. (Chp.2, 25-50). Published in the United States of America by IGI Global.

Orellana, M., Darder, A., Pérez, A. \& Salinas, J. (2016). Improving doctoral success by matching PhD students' with supervisors. International Journal of Doctoral Studies, 11, 87-103.

Overall, N., Deane, K. \& Peterson, E. (2011). Promoting doctoral students' research self-efficacy: combining academic guidance with autonomy support. Higher Education Research \& Development, 30, 791-805.

Park, C. (2005) New Variant PhD: The changing nature of the doctorate in the UK. Journal of Higher Education Policy and Management, 27, 189-207.

Pyhältö, K., Toom, A., Stubb, J. \& Lonka, K. (2012). Challenges of becoming a scholar: a study of doctoral students' problems and well-being. International Scholarly Research Network, 2012, 1-12.

Pyhältö, K., Vekkaila, J. \& Keskinen, J. (2012). Exploring the fit between doctoral students' and supervisors' perceptions of resource and challenges vis-à-vis the doctoral journey. International Journal of doctoral studies, 7, 395412.

Rahmati, Z. (2015). The study of academic burnout in students with a high and low level of self-efficacy. Procedia Social and Behavioral Sciences, 171, 49-55.

Ribau, I. \& Alves, M (2017). Doctoral supervision at NOVA LISBON UNIVERSITY: an exploratory study. The European Proceedings of Social \& Behavioural Sciences. http://dx.doi.org/10.15405/epsbs.2017.10.51

Ribau, I. \& Alves, M. (2018). Doctoral supervision at NOVA Lisbon University: an overview. Universal Journal of Educational Research, 6, 2530 - 2542 DOI: 10.13189/ujer.2018.061118. 
Ribau, I. (2018). Why should I enrol in a PhD? Students' perceptions about the reasons to be in a doctorate. Livro de capítulos do 6th International Congress of Educational Sciences and Development (Setúbal,

Portugal), 21-23 junho, 2018. https://www.congresoeducacion.es/edu_web6/LIBRO_RESUMENES.pdf Ribau, I. (2019). Listening and feeling doctoral students' perceptions of their doctoral supervision. The PhD students' point of view. Advances in Social Sciences Research Journal, 6 (12), 206-223. DoI:10.14738/assrj.612.7573.

Ribau, I. (2020). Doctoral Supervisors and PhD Students' Perceptions about the Supervision Process in a Young European University. Universal Journal of Educational Research. Vol 8 (1), 36-46. DOI:

10.13189/ujer.2020.080105

Ribau, I. (2020). The drop effect at the doctoral supervision sea surface. Observing the waves with supervisors' lens. Universal Journal of Educational Research. Vol 8 (4), 1579-1595.

Shibayama, S, \& Kobayashi, Y. (2017). Impact of PhD training: a comprehensive analysis based on a Japanese national doctoral survey. Scientometrics (2017) 113:387-415. DOI 10.1007/s11192-017-2479-7

Stracke, E. \& Kumar, V. (2010). Feedback and self-regulated learning: insights from supervisors' and PhD examiners' reports. Reflective Practice, 11, 19-32.

Sverdlik, A., Hall, N. C., McAlpine, L., \& Hubbard, K. (2018). The PhD experience: A review of the factors influencing doctoral students' completion, achievement, and well-being. International Journal of Doctoral Studies, 13, 361-388. https://doi.org/10.28945/4113

van Rooij, Els \& Fokkens-Bruinsma, Marjon \& Jansen, Ellen P.W.A.. (2019). Factors that influence PhD candidates' success: the importance of PhD project characteristics. Studies in Continuing Education.

10.1080/0158037X.2019.1652158.

Vekkaila, J., Pyhältö, K. \& Lonka, K. (2013). Focusing on doctoral students' experiences of engagement in thesis work. Frontline Learning Research, 2, 12-34.

Woolderink, M., Putnik, K., van der Boom, H., \& Klabbers, G. (2015). The voice of PhD candidates and PhD supervisors. A qualitative exploratory study amongst $\mathrm{PhD}$ candidates and supervisors to evaluate the relational aspects of $\mathrm{PhD}$ supervision in the Netherlands. International Journal of Doctoral Studies, 10, 217-235.

Yarwood-Ross L. \& Haigh C. (2014). As others see us: what PhD students say about supervisors. Nurse Researcher, 22, 1, 38-43. 